San Jose State University

SJSU ScholarWorks

Master's Theses

Master's Theses and Graduate Research

Spring 1985

\title{
An Evaluation of Screening Models for Assessing Toxic Air Pollution Downwind of Hazardous Waste Landfills
}

Lynton Worth Baker

San Jose State University

Follow this and additional works at: https://scholarworks.sjsu.edu/etd_theses

\section{Recommended Citation}

Baker, Lynton Worth, "An Evaluation of Screening Models for Assessing Toxic Air Pollution Downwind of Hazardous Waste Landfills" (1985). Master's Theses. 4571.

DOI: https://doi.org/10.31979/etd.v7zy-erg2

https://scholarworks.sjsu.edu/etd_theses/4571

This Thesis is brought to you for free and open access by the Master's Theses and Graduate Research at SJSU ScholarWorks. It has been accepted for inclusion in Master's Theses by an authorized administrator of SJSU ScholarWorks. For more information, please contact scholarworks@sjsu.edu. 
AN EVALUATION OF SCREENING MODELS FOR ASSESSING TOXIC

AIR POLLUTION DOWNWIND OF HAZARDOUS WASTE LANDFILLS

\author{
A Thesis \\ Presented to \\ The Office of Graduate Studies and Research \\ San Jose State University
}

\author{
In partial Fulfillment \\ of the Requirements for the Degree \\ Master of Science
}

By

Lynton Worth Baker

May, 1985 
APPROVED FOR THE OFFICE OF

GRADUATE STUDIES AND RESEARCH
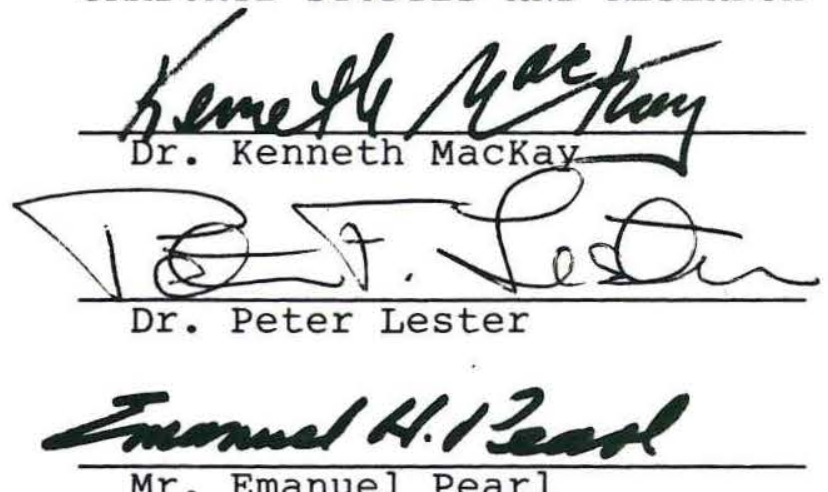

Mr. Emanuel Pearl

APPROVED FOR THE UNIVERSITY

Vames R.short 
ABSTRACT

The ambient air concentration of vinyl chloride downwind of the BKK Landfill in West Covina, CA is estimated using four air pollution screening models. BKK has accepted hazardous and municipal wastes since 1963. Disposal of waste solutions containing vinyl chloride was stopped in June, 1981 after exceedances of the California ambient air vinyl chloride standard were measured. Since then, however, vinyl chloride has continued to volatilize and diffuse to the landfill surface. The emission rate of vinyl chloride is estimated using pertinent landfill data including the concentration of vinyl chloride in landfill gas, the depth of the soil landfill cover, soil porosity, and the portion of the hilly landfill impacting two residential monitoring sites under different wind patterns. Due to the lack of onsite meteorological data, dispersion parameters in the screening models are estimated using data from the ontario International Airport, 15 miles east of the landfill. Performance of the screening models is evaluated by comparing model estimates to monitoring data. A virtual point source screening model, recommended by the U.S. EPA (1981), estimates measured concentrations of vinyl chloride at BKK with an average error of $8 \%$ and is suggested for assessing toxic air pollution downwind of other hazardous waste landfills. 


\section{ACKNOWLEDGEMENTS}

I wish to thank Dr. Kenneth Mackay, Dr. Peter Lester, and Mr. Emanuel Pearl for their comments and guidance in the preparation of this thesis. I also thank Hugh Rose of the South Coast Air Quality Management District, Arjun Arjaratman of the BKK Landfill, and Dr. Hanwant Singh of SRI International for the information they provided. 
TABLE OF CONTENTS

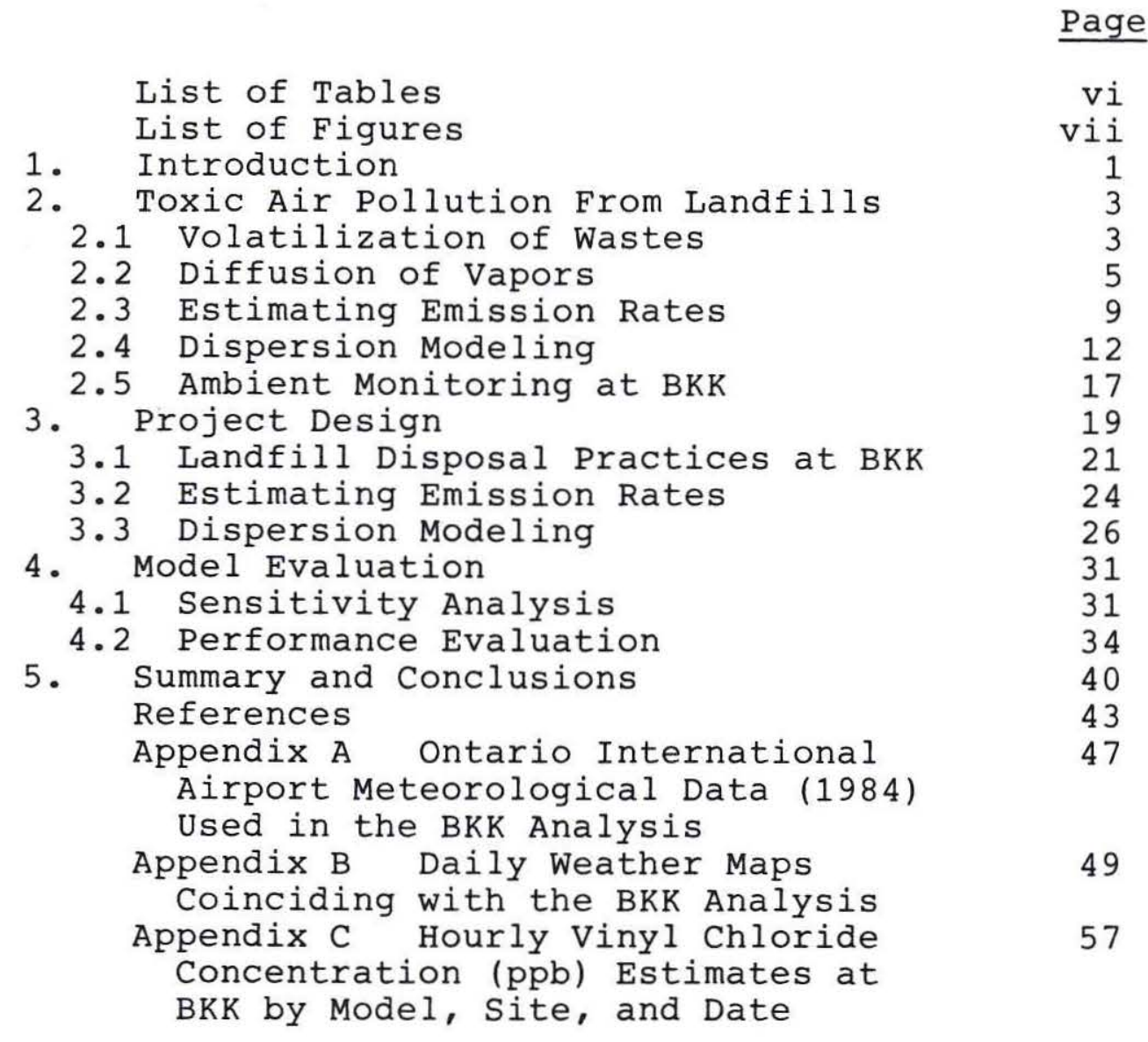




\section{LIST OF TABLES}

$\underline{\text { Table }}$

1

2

3

4

5

6

Title

Factors Affecting Volatilization of Organic Chemical Waste

Vapor Pressure of Vinyl Chloride at Different Temperatures

Factors Affecting Diffusion Through a Soil Landfill Cover

Diffusion Coefficient of Vinyl Chloride at Different Temperatures

Exposed Area of BKK Affecting Monitoring Sites $A$ and $B$ Under Different Wind Patterns

Emission Rate Input Data at BKK for March and August, 1984

Emission Rates (g/s) of Vinyl Chloride from BKK Affecting Monitoring Sites A and B for March and August, 1984 Under Different Wind Patterns

Model Evaluation and Measured Vinyl Chloride Concentrations (ppb) at BKK

Possible Error in Emission Rate Input Variables at BKK

Model Attributes in a Performance Evaluation

EPA/AMS Statistical Performance Measures for Assessing Model Attributes ppb)

Model Precision at BKK (Concentrations in $\mathrm{ppb})$

Linear Regression and Pearson Correlation coefficient at BKK 


\section{LIST OF FIGURES}

Figure

1

2

3 $\underline{\text { Title }}$

Topography of the Los Angeles Basin

Topography of BKK Landfill and Location

of Monitoring Sites A \& B

Location of $B K K$ relative to the ontario International Airport $\underline{\text { Page }}$

20

22

28 
CHAPTER 1

$\underline{\text { Introduction }}$

Toxic organic chemicals disposed in hazardous waste landfills volatilize over time, diffuse through the soil landfill cover to the surface, are dispersed downwind, and may cause health problems. Ambient air monitoring downwind of several hazardous waste landfills has revealed trace concentrations of carcinogens, mutagens, and teratogens (U.S. EPA, 1981). Simple air pollution dispersion equations called screening models have been used or proposed for estimating concentrations downwind of area sources such as landfills. Screening models are used in regulatory analyses of sources such as landfills to determine whether potential health threats or exceedances of air quality standards exist and whether ambient monitoring or more detailed computer modeling should be conducted. Sedefian (no date) and the U.S. EPA (1981) recommended screening models for assessing landfill air pollution without evaluating their performance. The objective of this project is to evaluate the performance of four screening models in estimating ambient vinyl chloride concentrations downwind of the $\mathrm{BKK}^{1}$ Landfill in West Covina, CA, a suburb of Los Angeles. The emission

1 BKK are the initials of the landfill founder. 
rate of vinyl chloride is first estimated, giving the landfill source strength. Vinyl chloride concentrations are estimated with the four screening models using meteorological and landfill input data representative of ambient air monitoring periods in March and August, 1984. Model estimates are then compared to measured vinyl chloride concentrations. Values of the relevant EPA/AMS (Tikvart and Cox, 1984) statistical performance measures quantify the accuracy and precision of each model. 


\section{Toxic Air Pollution From Landfills}

This chapter discusses volatilization, diffusion, estimation of emissions, and modeling and monitoring of ambient concentrations of vinyl chloride as related to the BKK Landfill. BKK is a co-disposal landfill, having received organic chemical waste (including vinyl chloride waste) and municipal waste. Vinyl chloride is a known carcinogen, mutagen, and teratogen (SCAQMD, 1982). In May, 1978, the California Air Resources Board (CARB) established an air quality standard for vinyl chloride of $10 \mathrm{ppb}$ for a 24-hour average to minimize risk resulting from exposure. Vinyl chloride is one of the few toxic air pollutants for which an air quality standard has been established. Used primarily in the synthesis of polyvinyl chloride (PVC), vinyl chloride (chloroethene, $\mathrm{C}_{2} \mathrm{H}_{3} \mathrm{Cl}$ ) has a molecular weight of 62.5 and is a colorless gas at standard temperature and pressure.

\subsection{Volatilization of Wastes}

Liquid or semi-solid organic chemical wastes disposed in landfills will volatilize, the vapors subsequently diffusing through the soil landfill cover to the surface. Factors affecting volatilization are listed in Table 1. 
TABLE 1: Factors Affecting Volatilization of Organic Chemical Waste

\begin{tabular}{|c|c|}
\hline Molecular $\frac{\text { Factor }}{\text { weight }} 1$ & $\begin{array}{l}\text { Compound } \frac{\text { Efect }}{\text { sith low mole- }} \\
\text { cular weights usually } \\
\text { volatilize more rapidly. }\end{array}$ \\
\hline Vapor pressure ${ }^{1}$ & $\begin{array}{l}\text { Compounds with high vapor } \\
\text { pressures usually vola- } \\
\text { tilize more rapidly. }\end{array}$ \\
\hline $\begin{array}{l}\text { Quantity of organic } \\
\text { chemical waste }\end{array}$ & $\begin{array}{l}\text { Volatilization rate is } \\
\text { independent of quantity. }\end{array}$ \\
\hline $\begin{array}{l}\text { Presence of other } \\
\text { organic chemical waste }\end{array}$ & $\begin{array}{l}\text { Volatilization rate is } \\
\text { independent of other } \\
\text { organic chemical waste. }\end{array}$ \\
\hline $\mathrm{pH}$ of the waste ${ }^{3}$ & $\begin{array}{l}\text { Affects reactions with } \\
\text { other chemical waste, } \\
\text { which could speed, slow, } \\
\text { or end volatilization. }\end{array}$ \\
\hline $\begin{array}{l}\text { Solubility of organic } \\
\text { chemical waste in any } \\
\text { soil moisture }\end{array}$ & $\begin{array}{l}\text { Soluble wastes vola- } \\
\text { tilize more slowly and } \\
\text { may be transported beyond } \\
\text { the landfill boundary by } \\
\text { laterally moving ground- } \\
\text { water. }\end{array}$ \\
\hline
\end{tabular}

$1^{1}$ Shen (1982)

${ }_{3}^{2}$ Dobbs and Cull (1982)

${ }^{3}$ Shen (1981)

The vapor pressure is calculated using the following equation (CRC, 1984):

$$
\log _{10} p=\frac{-0.05223 a}{T}+b \quad ;
$$

where $\mathrm{p}$ is the vapor pressure ( $\mathrm{mm} \mathrm{Hg}$ ) and $\mathrm{T}$ is the absolute temperature $\left({ }^{\circ} \mathrm{K}\right)$. The constants $\mathrm{a}$ and $\mathrm{b}$ are determined by substituting values of $\mathrm{p}$ and $\mathrm{T}$ (tabulated in $\mathrm{CRC}$ ) into (1) 
and solving the equation for the two constants (Weast, 1984). For vinyl chloride, $\mathrm{a}=24005, \mathrm{~b}=7.71$, and (1) becomes ${ }^{1}$ :

$$
\log _{10} p=7.71-1253.78 / \mathrm{T}
$$

The vapor pressure of vinyl chloride at different temperatures is shown in Table 2.

TABLE 2: Vapor Pressure of Vinyl Chloride at Different Temperatures

\begin{tabular}{|l|r|r|r|r|}
\hline Temperature $\left({ }^{\circ} \mathrm{C}\right)$ & 10 & 20 & 30 & 40 \\
\hline Vapor Pressure (mm Hg) & 1915 & 2712 & 3752 & 5086 \\
\hline
\end{tabular}

Source: CRC (1984)

\subsection{Diffusion of vapors}

Organic chemical vapors diffuse through the soil landfill cover and escape from the surface of the landfill. Landfill and waste characteristics affecting diffusion are listed in Table 3. Soil porosity and the amount of municipal waste co-disposed with organic chemical waste are

1 The Handbook of Chemistry and Physics no longer recommends the vapor pressure equation cited by Shen (1982) and others, which was as follows:

$$
\begin{aligned}
& \log _{10} p=B-0.2185 \mathrm{~A} / \mathrm{T} \quad \text { (in general) and, } \\
& \log _{10} \mathrm{p}=8.2028-1368.47 / \mathrm{T} \text { (for vinyl chloride). }
\end{aligned}
$$

At $30^{\circ} \mathrm{C}$, this latter equation overestimates the vapor pressure of vinyl chloride calculated using (1) by $30 \%$. 
important in determining landfill emission rates and are discussed further.

TABLE 3: Factors Affecting Diffusion Through a Soil Landfill Cover

\begin{tabular}{|c|c|}
\hline Porosit $\frac{\text { Factor }}{y^{1}}$ & $\begin{array}{l}\text { Increased poroctity allows } \\
\text { more diffusion and } \\
\text { emission. }\end{array}$ \\
\hline $\begin{array}{l}\text { Atmospheric pressure } \\
\text { fluctuations }{ }^{1}\end{array}$ & $\begin{array}{l}\text { Pumping action from pres- } \\
\text { sure fluctuations have } \\
\text { been found to enhance the } \\
\text { diffusion of benzene } \\
\text { through a soil layer by } \\
13 \% \text {. }\end{array}$ \\
\hline $\begin{array}{l}\text { Other organic chemical } \\
\text { waste }\end{array}$ & $\begin{array}{l}\text { Volatile chemicals } \\
\text { enhance diffusion; larger } \\
\text { quantities also enhance } \\
\text { diffusion. }\end{array}$ \\
\hline $\begin{array}{l}\text { Temperature gradient } \\
\text { between landfill bottom } \\
\text { and surface }\end{array}$ & $\begin{array}{l}\text { Large gradients between } \\
\text { a warm landfill interior } \\
\text { and a cool surface } \\
\text { enhance thermally-induced } \\
\text { diffusion. }\end{array}$ \\
\hline Wind speed & $\begin{array}{l}\text { Increased wind at the } \\
\text { surface enhances the } \\
\text { "wick effect," speeding } \\
\text { diffusion. }\end{array}$ \\
\hline $\begin{array}{l}\text { Amount of municipal } \\
\text { waste }\end{array}$ & $\begin{array}{l}\text { Anaerobic decomposition } \\
\text { of organic matter in } \\
\text { municipal waste produces } \\
\text { gases which accelerate } \\
\text { diffusion. }\end{array}$ \\
\hline Chemical reactions 4 & $\begin{array}{l}\text { Exothermic acid reactions } \\
\text { could increase thermal } \\
\text { diffusion. }\end{array}$ \\
\hline
\end{tabular}


TABLE 3 (Continued)

\begin{tabular}{|c|c|}
\hline $\begin{array}{l}\text { Thickness } q^{f} \text { soil land- } \\
\text { fill cover }\end{array}$ & $\begin{array}{l}\text { Increased thickness } \\
\text { increases diffusion time. } \\
\text { Considerable time before } \\
\text { placement of the final } \\
\text { cover will allow more } \\
\text { emission. }\end{array}$ \\
\hline Soil moisture content ${ }^{4}$ & $\begin{array}{l}\text { Moisture fills soil } \\
\text { pores, slowing diffusion. }\end{array}$ \\
\hline $\begin{array}{l}\text { Infiltration of surface } \\
\text { water }\end{array}$ & $\begin{array}{l}\text { Methane gas production } \\
\text { from anaerobic decomposi- } \\
\text { tion, which accelerates } \\
\text { diffusion, is enhanced by } \\
\text { some infiltration, } \\
\text { impeded by rapid infil- } \\
\text { tration, and slowed by no } \\
\text { infiltration. }\end{array}$ \\
\hline
\end{tabular}

$1_{\text {Thibodeaux et al. (1982) }}$

$2 \mathrm{CARB}(1982 \mathrm{a})$

3 U.S. EPA (1981)

4 shen (1981)

5 Rovers and Farquhar (1973)

Soil porosity is the ratio of the volume of voids to the total volume of soil aggregate, usually expressed as a percentage (Terzaghi and Peck, 1967). It represents the degree to which a gas can diffuse through a soil layer, with large porosities resulting in more diffusion. The landfill cap or soil cover porosity is the controlling parameter in the emission of organic chemical vapors diffusing through a landfill cover (Thibodeaux et al., 1982). Soil porosity is affected by such soil parameters as soil compaction, moisture content, and the type and amount of organic matter (Shen, 1982). Shen found the porosity of highly compacted 
soil or moist soil to be about $35 \%$, while dry, loosely packed soil had a porosity of $55 \%$. Shen used a value of $40 \%$ in an emission rate estimate through a landfill cover consisting of manure, paper mill sludge, and topsoil. Thibodeaux (1984) suggested using a porosity of $20 \%$ in screening techniques for landfills with undetermined porosities. Farmer (1984) suggested a value of $20 \%$ for compacted soils with low clay or loam content.

Anaerobic decomposition of organic material in municipal wastes generates gases such as methane, carbon dioxide, hydrogen, ammonia, and hydrogen sulfide (Shen, 1981). These gases accelerate diffusion of organic chemical vapors. Anaerobic decomposition can elevate internal landfill temperatures to $150^{\circ} \mathrm{F}$ (Pearl, 1984). The temperature of gases extracted from BKK ranged from $65-80^{\circ} \mathrm{F}$ in winter (SCAQMD, 1984) to $80-90^{\circ} \mathrm{F}$ in summer (Arjaratman, 1984). The diffusion coefficient (a measure of the rate of gaseous diffusion) has been empirically derived for several organic chemicals at different temperatures (Shen, 1982). The diffusion coefficient of vinyl chloride at different temperatures is shown in Table 4. 
TABLE 4: Diffusion Coefficient of Vinyl Chloride at Different Temperatures

\begin{tabular}{|l|c|c|c|c|}
\hline Temperature $\left({ }^{\circ} \mathrm{C}\right)$ & 10 & 20 & 30 & 40 \\
\hline $\begin{array}{l}\text { Diffusion } \\
\text { coefficient }\left(\mathrm{cm}^{2} / \mathrm{s}\right)\end{array}$ & .10094 & .10726 & .11375 & .12040 \\
\hline
\end{tabular}

Source: Shen (1982)

\subsection{Estimating Emission Rates}

This section discusses two methods of estimating landfill emission rates: one, which includes the diffusion enhancing effects of anaerobic decomposition and atmospheric pressure fluctuations, but which is not solvable for vapor pressures greater than $1 \mathrm{~atm}$, and another which considers soil porosity and the concentration of organic chemical waste in the landfill, but assumes that the diffusion of vapor is the only transport mechanism through the soil landfill cover.

Thibodeaux et al. (1984) estimated emission rates from:

$$
\mathrm{N}_{\mathrm{A}}=\left[\frac{\mathrm{VP}_{\mathrm{A}} \mathrm{M}_{\mathrm{A}} / \mathrm{RT}}{1-\mathrm{P}_{\mathrm{A}} / \mathrm{P}_{\mathrm{T}}-\exp \left[-\left(\mathrm{N}_{\mathrm{A}} / \mathrm{M}_{\mathrm{A}}+\mathrm{VP}_{\mathrm{T}} / \mathrm{RT}\right) \mathrm{LRT} / \mathrm{P}_{\mathrm{T}} \mathrm{D}\right]}\right] ;
$$

where: $\begin{aligned} & N_{A}=\text { volatile chemical flux }\left(\mathrm{g} / \mathrm{cm}^{2} \mathrm{~s}\right), \\ & V^{2}=\text { apparent bio-gas velocity }\left(\mathrm{cm}^{3} / \mathrm{cm}^{2} \mathrm{~s}\right)\end{aligned}$ (gas from decomposing organicmatter), $\mathrm{P}_{\mathrm{A}}=$ vapor pressure of the chemical (atm), $M_{A}^{A}=$ molecular weight $(\mathrm{g} / \mathrm{mole})$

$\mathrm{R}=$ gas constant $\left(82.1 \mathrm{~atm} \mathrm{~cm} / \mathrm{mole}^{\circ} \mathrm{K}\right)$, $\mathrm{T}=$ temperature $\left({ }^{\circ} \mathrm{K}\right)$, $\mathrm{P}_{\mathrm{T}}=$ atmospheric pressure (atm), $L^{T}=$ soil cover (cap) thickness $(\mathrm{cm})$, $\mathrm{D}$ = effective diffusion coefficient $\left(\mathrm{cm}^{2} / \mathrm{s}\right)$. 
This empirical equation is an extension of Fick's Law describing vapor diffusion through a soil layer. Eq. includes the effects of gas production from anaerobic decomposition, atmospheric pressure fluctuations, and the depth of the soil cover through which the vapor diffuses. The equation is independent of the concentration of the organic chemical waste in the landfill.

$\mathrm{N}_{\mathrm{A}}$ appears on both sides of (2) for cases in which $\mathrm{P}_{\mathrm{A}}>0.05 \mathrm{P}_{\mathrm{T}} \cdot \mathrm{Eq} \cdot(2)$ is solved by an iterative process initiated by substituting (3) into (2). For cases with no gas production $(\mathrm{V}=0)$ from anaerobic decomposition, Thibodeaux et al. (1984) use:

$$
\mathrm{N}_{\mathrm{A}}=\left(\mathrm{DP}_{\mathrm{T}} \mathrm{M}_{\mathrm{A}} / \mathrm{RTL}\right) \text { ln } \frac{1}{1-\mathrm{P}_{\mathrm{A}} / \mathrm{P}_{\mathrm{T}}} \text {. }
$$

Eq. (3) is not solvable for highly volatile compounds such as vinyl chloride with vapor pressures greater than 1 atm. Hence, (2) cannot be used to estimate the emission rate of vinyl chloride from BKK.

Shen (1981) estimated landfill emission rates from the following equation which is solvable for chemicals with vapor pressures greater than $1 \mathrm{~atm}$ : 


$$
E_{i}=D_{i} C_{s i}{ }^{A P} t^{4 / 3}(1 / L)\left(W_{i} / W\right) ;
$$

where: $E_{i}=$ emission rate of chemical $i(g / s)$,

$$
\begin{aligned}
D_{i}= & \text { diffusion coefficient }\left(\mathrm{cm}^{2} / \mathrm{s}\right), \\
\mathrm{C}_{\mathrm{S}}= & \text { saturated vapor concentration }\left(\mathrm{g} / \mathrm{cm}^{3}\right), \\
\mathrm{A} & =\text { exposed area }\left(\mathrm{cm}^{2}\right), \\
\mathrm{P}_{t}= & \text { soil porosity }(\mathrm{o}), \\
\mathrm{L} & =\text { effective depth of soil cover }(\mathrm{cm}), \\
\mathrm{W}_{\mathrm{i}} / \mathrm{W}= & \text { weight fraction of chemical } \mathrm{i} \text { in the } \\
& \text { landfill }(\mathrm{g} / \mathrm{g} \text { or } \mathrm{ppm}) .
\end{aligned}
$$

The saturated vapor concentration is calculated using the ideal gas law in the form:

$$
\mathrm{C}_{\mathrm{Si}}=\mathrm{pM} / \mathrm{RT} \quad ;
$$

where: $C_{S i}=$ saturated vapor concentration $\left(\mathrm{g} / \mathrm{cm}^{3}\right)$,

$\mathrm{p}=$ vapor pressure $(\mathrm{mm} \mathrm{Hg})$,

$M=$ molecular weight $(\mathrm{g} / \mathrm{mole})$,

$R=$ gas constant $\left(6.23 \times 10^{4} \mathrm{~mm} \mathrm{Hg} \mathrm{cm}{ }^{3} / \mathrm{mole}^{\circ} \mathrm{K}\right)$, $\mathrm{T}=$ absolute temperature $\left({ }^{\circ} \mathrm{K}\right)$.

Eq. (4) assumes that a given concentration of chemical waste will volatilize, resulting in a saturated vapor concentration. The vapor then diffuses through the soil landfill cover at a rate determined by the diffusion coefficient, the cover depth, and the porosity to yield the emission. The exponent on porosity (4/3) was empirically derived by Shen (1981).

In deriving (4), Shen modified the gas migration equation of Farmer et al. (1980), which was also based on Fick's Law. Migration equations estimate emission rates by using the difference in the landfill gas concentration between the surface and the landfill bottom assuming that 
the concentration gradient will produce diffusion out of the landfill. (The gas concentration at a landfill bottom is not commonly measured.)

The California ARB (CARB, 1982a) estimated that anaerobic gas production at co-disposal landfills causes organic chemical vapors to be transported through a soil landfill cover to the surface 4 to 16 times faster than if only organic chemical wastes are present. This faster gas diffusion was incorporated by multiplying (4) by an average emission rate enhancement factor of 6 , yielding:

$$
E_{i}=6 D_{i} C_{S i} A P_{t}^{4 / 3}(1 / L)\left(W_{i} / W\right)
$$

Thibodeaux et al. (1982) found that when biodegradeable waste was present, daily flux rates through a soil landfill cover of varying depth and porosity ranged from 37 to $290 \mathrm{~g}$ benzene $/ \mathrm{m}^{2}$. When no bio-gas was produced, daily flux rates decreased to between 10 and $30 \mathrm{~g}$ benzene/ $/ \mathrm{m}^{2}$. Thus, Thibodeaux et al. (1984) recommended a similar emission rate enhancement factor of 7 .

\subsection{Dispersion Modeling}

Ambient air concentrations of toxic organic chemical vapors downwind of landfills may be estimated using simple air pollution dispersion models called screening models. Shen (1982) estimated ambient concentrations and compared them to monitoring data around a landfill containing 5,000 
ppm PCB. Shen first used (4) to estimate the landfill emission rate. Then, although recommending use of the PAL (Point Area Line) computer model from EPA's UNAMAP (User's Network for Applied Modeling of Air Pollution) dispersion model series to estimate downwind PCB concentrations, shen used the Gaussian ground level point source model:

$$
\mathbf{X}=\frac{Q}{\pi \sigma_{y} \sigma_{z} \bar{u}} ;
$$

where: $\mathbf{X}=$ concentration $\left(\mathrm{g} / \mathrm{m}^{3}\right)$ at distance $\mathbf{x}(\mathrm{m})$ downwind,

$Q=$ source strength or emission rate $(\mathrm{g} / \mathrm{s})$, $\sigma_{y}=$ standard deviation of the horizontal plume concentration (m),

$\sigma_{z}=$ standard deviation of the vertical plume concentration (m),

$\overline{\mathrm{u}}=$ mean wind speed $(\mathrm{m} / \mathrm{s})$.

Shen compared the model estimate to ambient PCB samples collected with Tenax adsorbent cartridges. Tenax is appropriate for volatile, non-polar aromatic hydrocarbons but less appropriate for sampling PCB (Riggin, 1984), which is a polar molecule with low volatility. This places some question on the monitoring data and the model evaluation. The monitoring involved 24 hour samples. The stability was assumed to be neutral or Class D, roughly an average of nighttime stability and daytime instability. Winds were averaged for the 24 hour sampling period. The temperature at the surface of the landfill was used in determining the vapor pressure and the diffusion coefficient for the diffusing $\mathrm{PCB}$. 
Three area source dispersion equations are appropriate for evaluation as screening models to estimate concentrations downwind of landfills. Turner (1969) modified (7) to apply to a square area source represented by a virtual upwind point source. The standard deviation $\sigma_{y}$ is replaced by $\sigma_{\mathrm{y} 1}=\sigma_{\mathrm{y} 0}+\sigma_{\mathrm{y}}$, where $\sigma_{\mathrm{y} 0}=\mathrm{s} / 4.3$, s being the length of a side of the landfill in meters. The virtual upwind distance is $\mathrm{x}_{\mathrm{y}^{*}}$ Eq. (7) is used, calculating $\sigma_{\mathrm{y} 1}$ at a distance of $\mathrm{x}+\mathrm{x}_{\mathrm{y}}$. The standard deviation $\sigma_{\mathrm{z}}$ is calculated at the downwind distance $x$, taken to be the distance from the downwind receptor to the downwind landfill border plus the distance from the border to the center of the landfill or s/2. Raygor (1973) found that this method "accurately predicts downwind concentrations" from an area source (not a landfill).

The U.S. EPA (1981) recommended a similar virtual upwind point source dispersion equation:

$$
\mathbf{X}=\frac{16(2 Q)}{2 \pi L_{\mathrm{V}} \sqrt{2 \pi}} \sigma_{\mathrm{z}} \overline{\mathrm{u}}
$$

All variables are as in (7) except $L_{v}$, which is the virtual downwind distance to the receptor. The distance $\mathrm{L}_{\mathrm{v}}$ is the sum of $L$, the distance from the landfill center to the receptor and L', the distance from the upwind virtual point source to the landfill center. The distance $L^{\prime}$ is given by:

$$
L^{\prime}=(\mathrm{S} / 2) \cot \left(22.5^{\circ} / 2\right) ;
$$


where $S$ is the width in meters of the landfill perpendicular to the wind direction. The standard deviation $\sigma_{z}$ is based on $\mathrm{L}$, not $\mathrm{L}_{\mathrm{V}}$. EPA stated that if the source width is greater than $40 \%$ of the distance from the source center to the receptor, this virtual point source approach would lead to less reliable concentration estimates.

Sedefian (no date) recommended the simple box model of Gifford and Hanna (1970):

$$
\mathrm{C}=\frac{\mathrm{KQ}}{\mathrm{u}} ;
$$

$$
\text { where: } \begin{aligned}
& \mathrm{C}=\text { concentration }\left(\mathrm{g} / \mathrm{m}^{3}\right), \\
& \mathrm{Q}=\text { area source emission rate }\left(\mathrm{g} / \mathrm{m}^{2} \mathrm{~s}\right), \\
& \mathrm{u}=\text { wind speed }(\mathrm{m} / \mathrm{s}) \mathrm{-}-\mathrm{b}) \\
& \mathrm{K}=(2 / \pi) \frac{(\mathrm{s} / 2)(1-\mathrm{l})}{\mathrm{a}(1-\mathrm{b})} \\
& \mathrm{s}=\text { length of a side of an area source }(\mathrm{m}), \\
& \mathrm{a}=0.15, \\
& \mathrm{~b}=0.75 .
\end{aligned}
$$

The values of $a$ and $b$ were based on the Pasquill-Gifford stability parameters for neutral conditions with sampling periods of 24 hours or longer.

The standard deviations, $\sigma_{\mathrm{y}}$ and $\boldsymbol{\sigma}_{\mathrm{z}}$, in these screening models are based on the Pasquill-Gifford diffusion estimates, incorporated by Turner (1969) into a set of curves which are a function of stability class and downwind distance. Turner (1976) recommended modifying Pasquill's original stability classification scheme for use with an area source in an urban area. Turner's revised stability categories incorporate increased roughness and instability 
over urban environments, and could apply at BKK because of the hilly terrain.

Warm gases from anaerobic decomposition of the organic material in municipal waste will slightly increase the diffusion of the organic chemical vapors and, upon reaching the surface, being buoyant if the air temperature is cooler, contribute to a slight plume rise. However, gas velocities leaving landfills have been measured as slow as $1.6 \times 10^{-3}$ $\mathrm{cm} / \mathrm{s}$ (Thibodeaux, 1981). The Davidson-Bryant and Bosanquet plume rise equations (Slade, 1968) calculate a plume rise under these conditions at less than 1 meter, which may be neglected in dispersion equations. Thus, the effective release height is at ground level.

Area source dispersion models more detailed than screening models which might be appropriate for use downwind of landfills are four of EPA's UNAMAP dispersion models: PAL (Point Area Line source Gaussian plume dispersion model), ISCST (Industrial Source Complex-Short Term Gaussian plume dispersion model), RAM (a multiple-source Gaussian plume model), and VALLEY (a Gaussian plume model with terrain adjustment). RAM and PAL are quite similar in their area source input data, and dispersion and analytic geometry equations (Novak and Turner, 1976). However, RAM does not allow variable emissions data while PAL allows varying hourly emissions data to match changing meteorological conditions. 
2.5 Ambient Monitoring at BKK

Vinyl chloride monitoring data were collected by the SCAQMD at two locations near BKK (Rose, 1984). Monitoring samples were collected using 24 hour Tedlar bag samples. The samples were analyzed by gas chromatography/flame ionization detection (SCAQMD, 1982). The sampling period was 10:00 a.m. local time (LT) to 10:00 a.m. the following day. Tedlar bags are an accepted method for sampling vinyl chloride in ambient air (Riggin, 1983). A comparison of bag sampling $(x)$ versus an automatic flame ionization detector/ gas chromatograph (y) for vinyl chloride had a linear regression in $\mathrm{ppb}$ of $\mathrm{y}=0.78 \mathrm{x}+7.31$, with a correlation coefficient of 0.94 (SCAQMD, 1982). The accuracy of the continuous analyzer was not reported. A further comparison of SCAQMD bag sampling $(x)$ versus CARB bag sampling (y) yielded a linear regression of $y=1.02 x+0.91$, with a correlation coefficient of 0.97. Carbon molecular sieve solid adsorbents or cryogenic trapping are also acceptable methods for monitoring chemicals as volatile as vinyl chloride (Riggin, 1984).

Two PVC manufacturing plants are located about 25 miles southwest of BKK, upwind during daytime sea breeze conditions. However, these plants should not affect the concentrations measured at BKK considering the large distance for dispersal and that higher concentrations have been measured near BKK than near these plants (SCAQMD, 1982). Therefore, 
background vinyl chloride concentrations around BKK should be near zero. 


\section{CHAPTER 3}

\section{Project Design}

Information from the BKK Landfill was used to estimate the emission rate and ambient downwind concentration of vinyl chloride. The performance of four screening models was evaluated by comparing concentration estimates to monitoring data from two monitoring sites near BKK. The monitoring data consisted of two days in March and three days in August, 1984.

BKK is located in the Los Angeles Basin. The Basin is surrounded by mountains to the north and east which rise to as high as 10000 feet above mean sea level (msl). In addition to these mountains which limit horizontal dispersion of air pollutants, vertical dispersion is limited by an inversion based below 2500 feet msl on $90 \%$ of the days (Keith, 1980).

Fig. 1 shows the San Gabriel Mountains which form the northern boundary of the Basin. BKK is situated in the southwestern slopes of the San Jose Hills. Other geographical features in the vicinity of BKK are the Puente Hills to the southwest and south, the Chino Hills to the southeast, and the San Gabriel River valley to the west, near El Monte.

The mild climate of the Basin is characterized by a fairly regular daily reversal of wind direction with a daytime westerly (onshore) sea breeze and a nighttime 


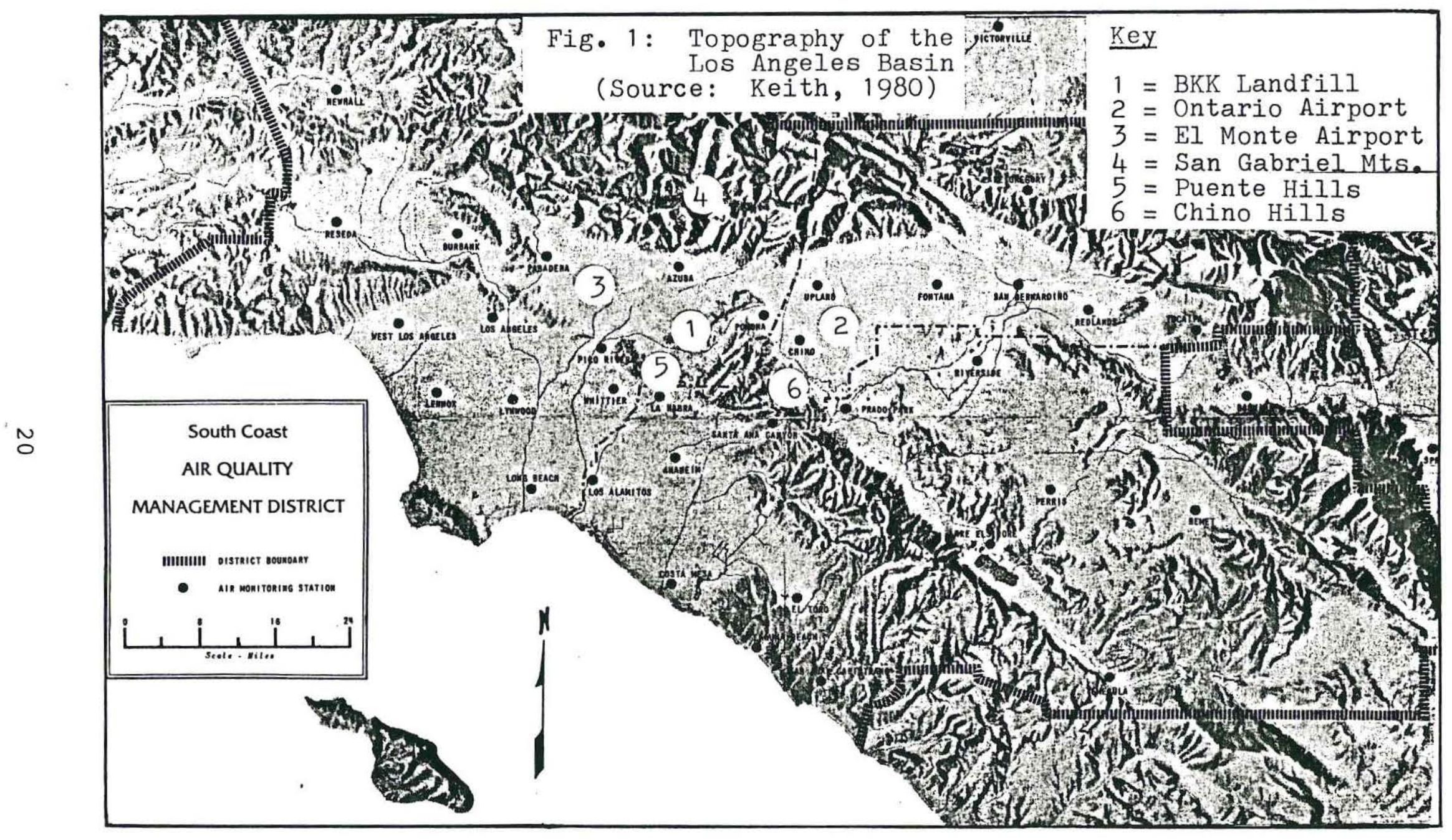


(offshore) downslope drainage wind from the north and east, depending on proximity to hills. The sea breeze is about twice as strong as the nighttime drainage wind and lasts longer during the summer (Keith, 1980). The downslope drainage wind usually begins along mountain slopes after midnight on most summer nights and starts shortly after sunset during the winter.

\subsection{Landfill Disposal Practices at BKK}

The BKK landfill has been one of the largest landfills in California, at one time receiving $20 \%$ of the state's volatile organic chemical waste disposed at landfills (CARB, 1982b). BKK is a co-disposal landfill, having received hazardous chemical waste (including vinyl chloride waste) and municipal waste containing large amounts of organic material since 1963. Disposal of waste solutions from the synthesis of PVC consisting of vinyl chloride monomer and precursors to vinyl chloride such as ethylene dichloride (Arjaratman, 1984) were stopped in June, 1981 after exceedances of the California ambient air vinyl chloride standard were measured (CA DOHS, 1983).

Fig. 2 shows the hilly terrain of BKK which ranges in elevation from 600 to 1150 feet msl. BKK covers 583 acres of which 228 acres contain hazardous and municipal waste (Arjaratman, 1984). In the main portion of BKK a canyon has been filled with several layers (called lifts) of waste, 


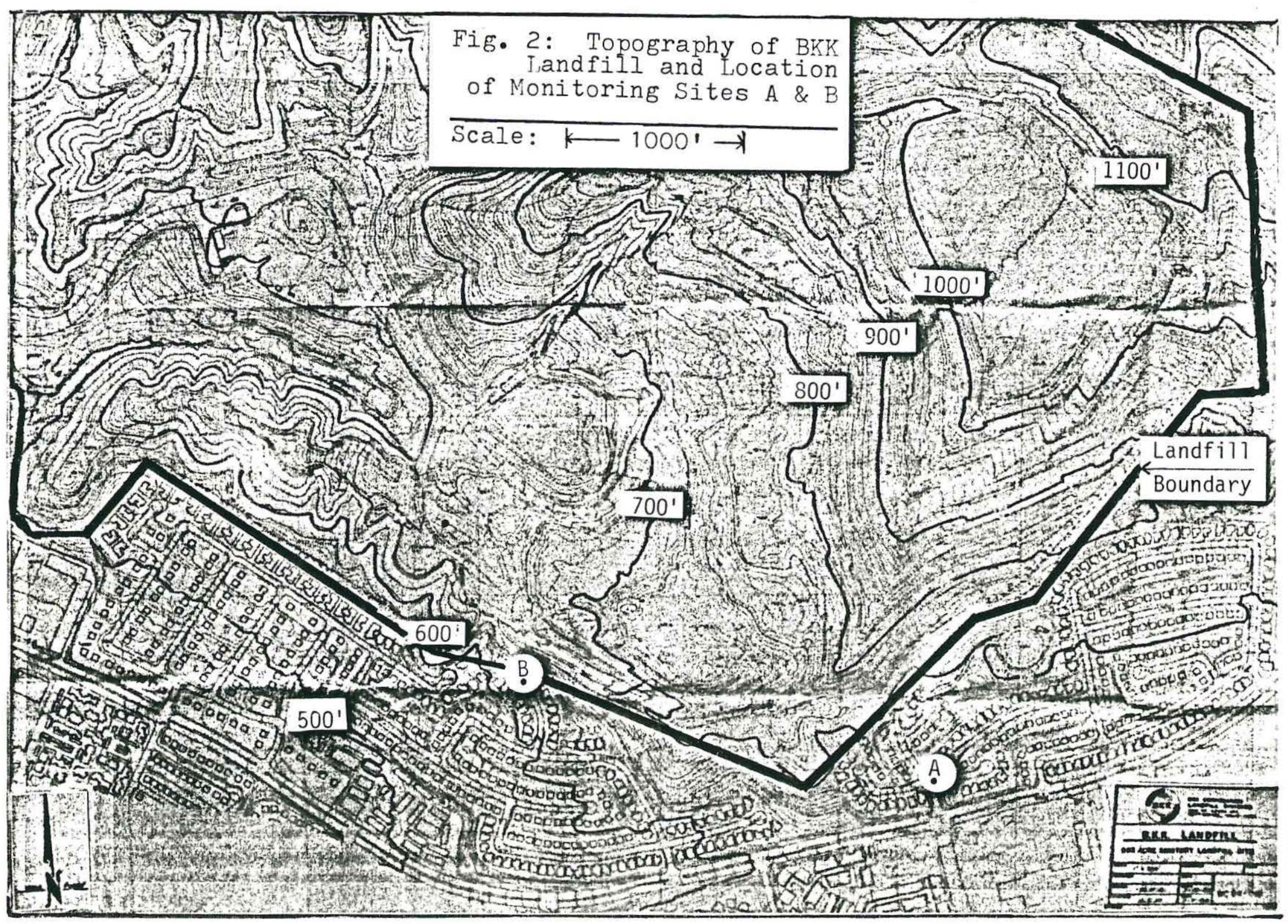


each about twenty feet deep, to a total depth of 50 to 150 feet. On the hillsides of the landfill, wastes are deposited in trenched terraces, each about twenty feet deep. At the end of each working day the newly deposited waste is covered with three feet of compacted soil (Arjaratman, 1984) to prevent material from being blown from the lifts and to serve as a barrier to odors, vectors, fire, and infiltration of water (CA SWMB, 1978). The volatilization rate can be much greater when the lifts are uncovered than after covering. Once a portion of the landfill has been completed, a final cover of five to ten feet of compacted soil is spread atop the daily covers. The final cover may be placed almost immediately if a given slope has been filled to capacity or may not be placed for several months if a slope can be filled with more layers of waste (Arjaratman, 1984).

Gases from the volatilizing organic chemical waste and the decomposing municipal waste are extracted under a slight suction through pipes extending as deep as 150 feet into the landfill as part of a gas collection system (SCAQMD, 1982). The gases, primarily methane, are then sent by blowers to be burned at the surface in smokeless flares. This gas collection helps reduce the quantity of escaping gases affecting nearby residences. The depth to which the pipes extend varies throughout the landfill. The vinyl chloride concentration in the gas collection system ranged from 120 to 470 
ppm during a March 9, 1984 source test and, for the entire gas collection system, averaged $330 \mathrm{ppm}$ (SCAQMD, 1984).

\subsection{Estimating Emission Rates}

The emission rate of vinyl chloride from BKK was estimated using (6). The diffusion coefficient and saturated vapor concentration were determined by the methods discussed in sections 2.1 - 2.3. The temperature of extracted gases was $20^{\circ} \mathrm{C}$ for the March, 1984 period (SCAQMD, 1984) and $30^{\circ} \mathrm{C}$ for the August, 1984 period (Arjaratman, 1984). The concentration of vinyl chloride in the extracted landfill gases was used to approximate the vinyl chloride concentration in the landfill, assuming that the concentration of highly volatile vinyl chloride was uniform throughout the landfill and that the vinyl chloride concentration in the landfill gas approximated the vinyl chloride concentration in solution in the landfill.

An average total final landfill cover (daily plus final) of ten feet of soil was used as the effective depth of the soil cover in (6). The porosity was estimated using Thibodeaux's (1984) suggested value of $20 \%$

The portion of the landfill emitting vinyl chloride which impacts monitoring sites $A$ and $B$ varies under different wind directions due to the hilly terrain of BKK. Fig. 2 shows the topography at BKK, the location of the monitoring sites, and the adjacent residential areas. The 
original topographical map (scale of $1^{\prime \prime}=200^{\prime}$ ) of BKK and topographical maps of the surrounding valley were studied along with the wind data so that the exposed area in (6) was varied to reflect different wind patterns at the two monitoring sites.

Most of the vinyl chloride measured at sites A and B was a result of nighttime downslope drainage winds (Rose, 1984). A hill sloping upward to the north of site A allowed considerable area for drainage. A ridge north of site B appeared to direct most nighttime draining air and emissions away from this site. Because both monitoring sites were on the southern side of the landfill and the sea breeze frequently blew from the southwest, about half of each day received no emissions since the landfill was downwind of the monitoring sites. The exposed area used in (6) and the corresponding wind patterns for the two monitoring sites are shown in Table 5. Table 6 shows the input values of the other parameters in (6).

TABLE 5: Exposed Area of BKK Affecting Monitoring Sites $A$ and $B$ Under Different Wind Patterns

\begin{tabular}{|ccccc|}
\hline Site & Exposed Area $\left(\mathrm{cm}^{2}\right)$ & & Wind Direction & Wind Pattern \\
\cline { 5 - 6 } A & $2.60 \times 10^{8}$ & & $330^{\circ}-010^{\circ}$ & Hillside drainage \\
& $1.67 \times 10^{8}$ & & $270^{\circ}-290^{\circ}$ & Sea breeze \\
B & $0.31 \times 10^{8}$ & & $350^{\circ}-030^{\circ}$ & Hillside drainage \\
& $1.86 \times 10^{8}$ & $100^{\circ}-110^{\circ}$ & Valley drainage \\
\hline
\end{tabular}


TABLE 6: Emission Rate Input Data at BKK for March and August, 1984

\begin{tabular}{|ccc|}
\hline Eq. (6) Variable & March Estimate & August Estimate \\
\cline { 2 - 3 } $\mathrm{D}_{i}\left(\mathrm{~cm}^{2} / \mathrm{s}\right)$ & 0.10726 & 0.11375 \\
$\mathrm{C}_{\mathrm{Si}}\left(\mathrm{g} / \mathrm{cm}^{3}\right)$ & $9.28 \times 10^{-3}$ & $1.24 \times 10^{-2}$ \\
$\mathrm{P}_{\mathrm{t}}(\mathrm{g} / 100)$ & varies as shown in TABLE 5 \\
$\mathrm{w}_{\mathrm{L}} / \mathrm{w}(\mathrm{cm} / \mathrm{g}$ or $\mathrm{ppm})$ & 0.20 & $0.20^{2}$ \\
\hline
\end{tabular}

Emission rates were calculated for each hour of the five days used in this analysis. Table 7 summarizes the emission rate values appropriate to each monitoring site under different wind patterns.

TABLE 7: Emission Rates ( $\mathrm{g} / \mathrm{s}$ ) of Vinyl Chloride from BKK Affecting Monitoring Sites A and B for March and August, 1984 Under Different Wind Patterns

\begin{tabular}{|c|c|c|c|c|}
\hline Date & Site & $\begin{array}{l}\text { Hillside } \\
\text { Drainage }\end{array}$ & $\begin{array}{c}\text { Sea } \\
\text { Breeze }\end{array}$ & $\begin{array}{c}\text { Valley } \\
\text { Drainage }\end{array}$ \\
\hline March, 1984 & $\begin{array}{l}\text { A } \\
\text { B }\end{array}$ & $\begin{array}{l}0.197 \\
0.023\end{array}$ & 0.126 & 0.141 \\
\hline August, 1984 & $\begin{array}{l}A \\
B\end{array}$ & $\begin{array}{l}0.279 \\
0.033\end{array}$ & 0.179 & 0.199 \\
\hline
\end{tabular}

\subsection{Dispersion Modeling}

The ground level point source model (Shen, 1982), two virtual point source approximations to area source models (Turner, 1969 and U.S. EPA, 1981), and the simple box model (Gifford and Hanna, 1970) estimated downwind vinyl chloride concentrations. The point source model (Shen, 1982) was included for comparison because of previous use. 
The ambient vinyl chloride concentration was estimated at the same distance downwind of the southern boundary of BKK as the two monitoring sites. From a detailed topographical map, site $A$ was estimated to be 183 meters from the south-southeast landfill border. Site B was estimated at 23 meters from the south landfill border.

The lack of on-site meteorological data necessitated the use of hourly data from the ontario International Airport, fifteen miles east of the landfill, to estimate landfill wind and stability conditions. Data from the El Monte Airport, about nine miles northwest of BKK, were unavailable. Fig. 3 shows the location of $B K K$ relative to the Ontario Airport. Available hourly data from the ontario Airport included wind speed and direction, air temperature, and sky cover. Sky cover was used in estimating the Pasquill atmospheric stability categories (Turner, 1976). Appendix A contains the wind speed, direction, and stability data. Weather maps for the study period (Appendix B) show that no major synoptic feature passed over the Los Angeles Basin on any of the days and that surface winds were not a result of a large pressure gradient.

Most of the vinyl chloride measured at sites $A$ and $B$ resulted from nighttime downslope drainage winds. When the Ontario Airport reported a wind direction between $330^{\circ}$ and $030^{\circ}$, with a speed less than 6 knots, the wind pattern at BKK was assumed to be downslope drainage. Ontario Airport 


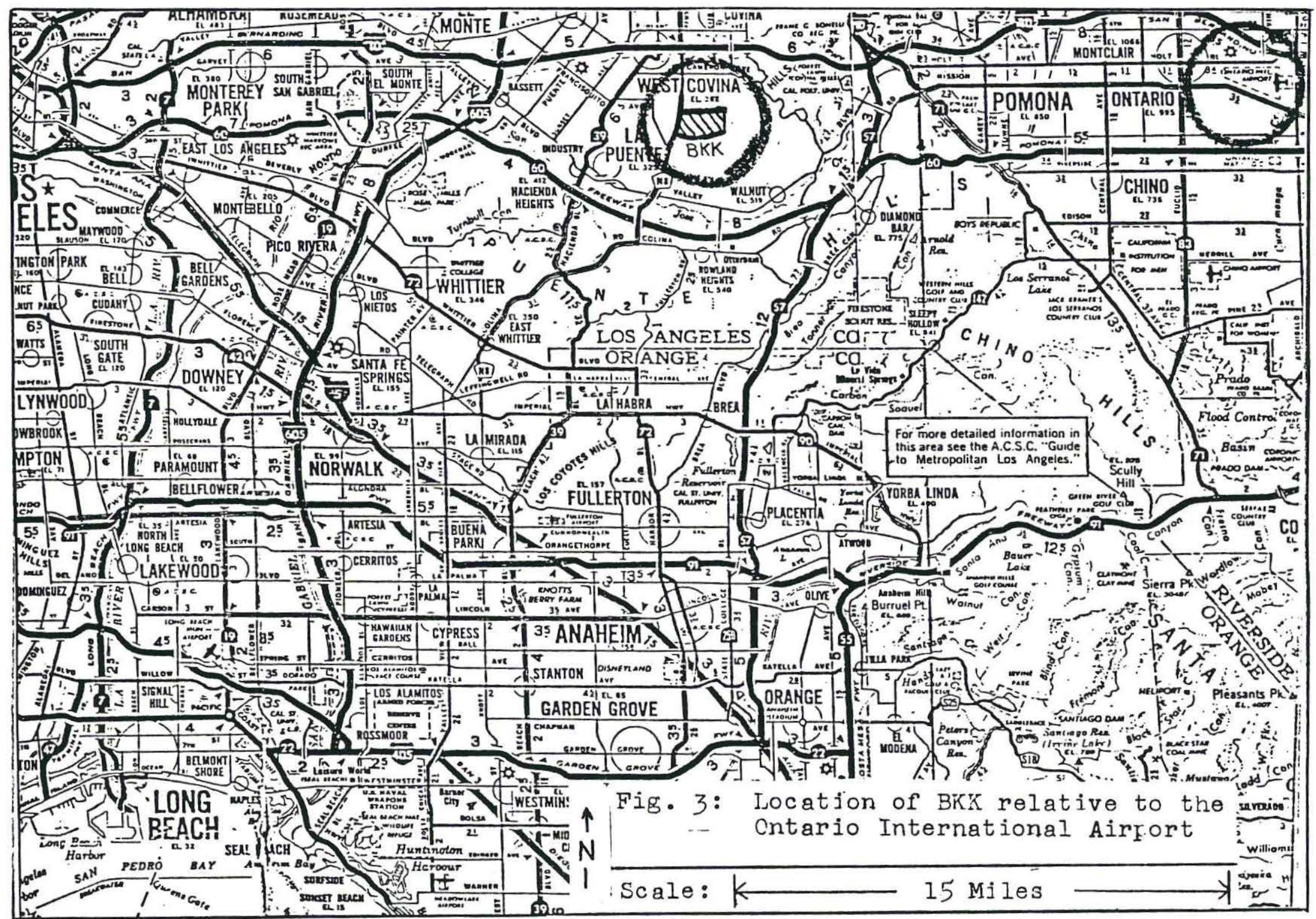


reported several hours each night of downslope conditions. A wind speed of $1 \mathrm{~m} / \mathrm{s}$ was used in the dispersion equations for hours when the ontario Airport reported calm winds. Concentrations were estimated on an hourly basis for the five days studied and are contained in Appendix C. (All hourly concentration estimates were well below the 8 hour OSHA standard for vinyl chloride of 1 ppm.) Table 8 shows the 24 hour and five day average estimated and measured vinyl chloride concentrations at sites $A$ and $B$.

The March period coincided with a March 9, 1984 source test of the landfill gas temperature and vinyl chloride concentration. The August data were used for comparison when the landfill gas temperature was warmer. The concentration of vinyl chloride in the landfill gas in August was assumed constant, although the concentration should be less than the March source test because no vinyl chloride monomer waste solution had been legally disposed at BKK since 1981 (CA DOHS, 1983). An estimation of this August landfill gas concentration would not be accurate. 
TABLE 8: Model Estimates and Measured Vinyl Chloride Concentrations (ppb) at BKK

\begin{tabular}{|c|c|c|c|c|c|c|c|}
\hline Site & Date & $\begin{array}{l}\text { Mar. } \\
7-8\end{array}$ & $\begin{array}{l}\text { Mar. } \\
8-9\end{array}$ & $\begin{array}{l}\text { Aug. } \\
5-6\end{array}$ & $\begin{array}{l}\text { Aug. } \\
6-7\end{array}$ & $\begin{array}{l}\text { Aug. } \\
7-8\end{array}$ & Average \\
\hline A & \begin{tabular}{cc}
\multicolumn{2}{l}{ Measured } \\
Model & 1 \\
" & 2 \\
" & 3 \\
" & 4 \\
\end{tabular} & $\begin{array}{r}12 \\
25.1 \\
9.1 \\
4.9 \\
45.9 \\
\end{array}$ & $\begin{array}{r}5 \\
19.4 \\
7.3 \\
4.0 \\
42.8 \\
\end{array}$ & $\begin{array}{r}7 \\
40.0 \\
14.8 \\
8.0 \\
76.7 \\
\end{array}$ & $\begin{array}{r}12 \\
45.7 \\
16.7 \\
9.0 \\
81.1 \\
\end{array}$ & $\begin{array}{r}9 \\
45.5 \\
16.9 \\
9.1 \\
87.3 \\
\end{array}$ & $\begin{array}{r}9 \\
35.1 \\
13.0 \\
7.0 \\
66.8 \\
\end{array}$ \\
\hline B & \begin{tabular}{cc}
\multicolumn{2}{l}{ Measured } \\
Model & 1 \\
" & 2 \\
" & 3 \\
" & 4
\end{tabular} & $\begin{array}{r}5 \\
24.3 \\
11.5 \\
5.5 \\
35.5\end{array}$ & $\begin{array}{r}7 \\
13.1 \\
6.1 \\
3.7 \\
28.6\end{array}$ & $\begin{array}{r}2 \\
30.4 \\
14.2 \\
8.4 \\
62.8\end{array}$ & $\begin{array}{r}4 \\
32.4 \\
15.3 \\
8.7 \\
62.0\end{array}$ & $\begin{array}{r}<2 \\
32.2 \\
15.2 \\
8.9 \\
66.7\end{array}$ & $\begin{array}{r}4 \\
26.5 \\
12.5 \\
7.0 \\
51.1\end{array}$ \\
\hline
\end{tabular}

Key

Model 1 = Ground level point source (Shen, 1982)

" 2 = Virtual point source (Turner, 1969)

" 3 = Virtual point source (U.S. EPA, 1981)

" 4 = Simple box (Gifford and Hanna, 1970) 
CHAPTER 4

\section{Model Evaluation}

The EPA and the AMS (American Meteorological Society) have agreed on statistical measures to be used in evaluating the performance of air pollution dispersion models (Tikvart and Cox, 1984). The EPA/AMS measures include bias (average and median), noise/scatter (variance, gross variability, average absolute residual), Pearson correlation coefficient, and frequency distribution comparison. The evaluation presented here includes a sensitivity analysis and EPA/AMS statistical performance measures of accuracy, precision, and correlation.

\subsection{Sensitivity Analysis}

The purpose of a sensitivity analysis is to identify input variables critical to good model performance, potential error in these input variables, and the decrease in model accuracy caused by input error. The models are assumed to be accurate in their formulation.

Each meteorological and source related input parameter may be systematically varied so that the model error may be quantitatively analyzed, as done by Freas and Lee (1976). For this sensitivity analysis, the screening models will be analyzed qualitatively. The emission rate equation, (6), will be analyzed quantitatively. 
Sedefian (no date) and U.S. EPA (1981) gave brief sensitivity analyses of their respective screening models. At BKK, use of off-site meteorological data may have led to error in the meteorological input variables. Without onsite wind speed and direction data, the frequency and magnitude of eddies, occurring as a result of flow across the hilly landfill, could not be detected. Eddies may have been the cause of the apparent negative correlation in Table 8 between the monitoring data and the model estimates at site $B$.

The emission rates calculated from (6) are susceptible to error resulting from approximating undetermined source related input variables. The values of variables used in (6) were shown in Table 6. Table 9 lists the possible error for four of these input variables, based on information in sections $2.2,2.3,3.1$, and 3.2 .

TABLE 9: Possible Error in Emission Rate Input Variables at BKK

\begin{tabular}{|l|c|c|}
\hline \multicolumn{1}{|c|}{ Variable } & Minimum & Maximum \\
\hline $\begin{array}{l}\text { Emission rate } \\
\text { enhancement factor }\end{array}$ & 4 & 7 \\
$\begin{array}{l}\text { Exposed area } \\
\text { (site A) }\end{array}$ & $1.3 \times 10^{8} \mathrm{~cm}^{2}$ & $5.2 \times 10^{8} \mathrm{~cm}^{2}$ \\
Porosity & 0.20 & 0.35 \\
$\begin{array}{l}\text { Depth of } \\
\text { soil cover (1/L) }\end{array}$ & $396.2 \mathrm{~cm}$ & $243.8 \mathrm{~cm}$ \\
\hline
\end{tabular}


The magnitude of the error in the emission rate may be quantitatively estimated by logarithmically differentiating (6) for the variables in Table 9, yielding:

$$
\frac{\Delta E_{i}}{E_{i}}=\frac{\Delta \text { (enhancement factor) }}{6}+\frac{\Delta A}{A}+\frac{4 / 3\left(\Delta P_{t}\right)}{P_{t}}-\frac{\Delta L}{L} \cdot
$$

Summing (11) for the minimum and maximum errors listed in Table 9 results in an error of from $-113 \%$ to $237 \%$ of the emission rate used in this model evaluation. Since the emission rate is used in the screening models, concentration estimates could have the same error.

The factors behind these possible errors are as follows: variation of the emission rate enhancement factor with the amount of municipal waste; difficulty of approximating the size of the exposed area which affects a monitoring site for this hilly landfill (an error of plus or minus $50 \%$ was used in Table 9); variation of soil porosity with soil compaction and composition; variation of the depth of the landfill cover from hillsides to flat fill areas.

Minimal error is expected in the remaining variables in (6). The assumption that the landfill vinyl chloride concentration in August was the same as in March may have led to some error, but the average landfill gas concentration used should be a good estimate. The diffusion coefficient was empirically derived. The saturated vapor concentration 
was calculated based on known or well-approximated variables. An undetermined but probably small error may be due to lateral movement of ground water above impermeable layers, which transports vapors and causes emissions beyond landfill boundaries.

\subsection{Performance Evaluation}

Screening models used to estimate concentrations downwind of landfills should be able to accurately predict peak concentrations so that if concentrations are predicted within an action level of a health or air quality standard, a regulatory agency can either conduct ambient air monitoring or more detailed modeling. Model attributes to consider in evaluating the performance of a model are listed in Table 10. For screening models, the first three attributes must be satisfied (Hayes, 1979).

TABLE 10: Model Attributes in a Performance Evaluation

\begin{tabular}{ll}
\hline 1) & Accuracy of the peak prediction \\
2) Absence of systematic bias \\
3) Lack of gross error \\
4) Temporal correlation \\
5) Spatial alignment \\
\hline
\end{tabular}

Source: Hayes (1979) 
EPA/AMS statistical performance measures useful in assessing model attributes are listed in Table 11.

TABLE 11: EPA/AMS Statistical Performance Measures for Assessing Model Attributes

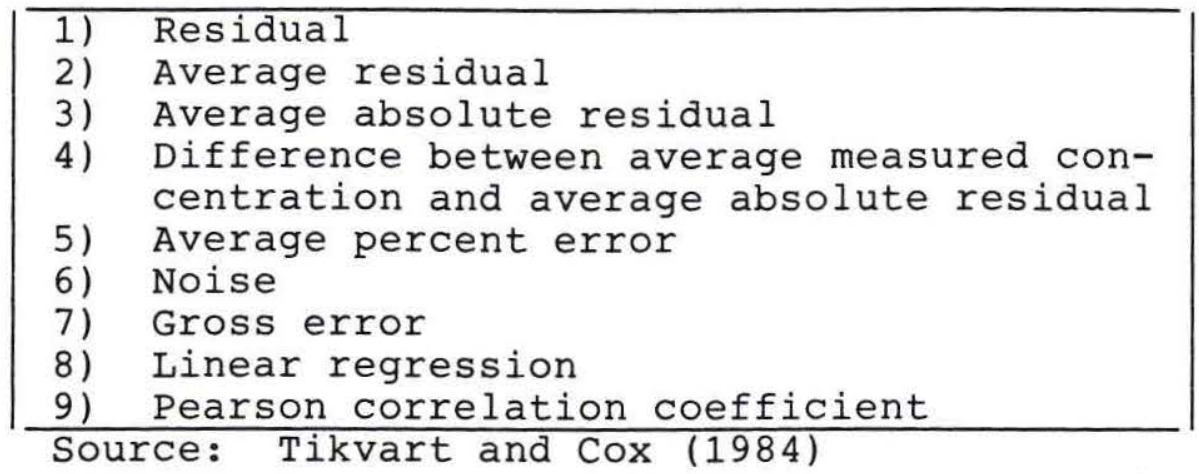

In the calculations of these performance measures, $\mathrm{C}_{0}$ represents the observed concentrations and $c_{p}$ represents the model predictions. Models 1-4 are the same as in Table 8. A discussion of the statistical results follows the calculations.

Model accuracy, the deviation from the measured concentration, is assessed using the performance measures calculated in Table 12. 
TABLE 12: Model Accuracy at BKK (Concentrations in ppb)

\begin{tabular}{|c|c|c|c|c|c|c|}
\hline \multicolumn{7}{|c|}{ Residual $=C_{0}-C_{p}=\Delta c$} \\
\hline Site & Date & $\begin{array}{l}\text { Mar. } \\
7-8\end{array}$ & $\begin{array}{l}\text { Mar. } \\
8-9\end{array}$ & $\begin{array}{l}\text { Aug. } \\
5-6\end{array}$ & $\begin{array}{l}\text { Aug. } \\
6-7 \\
\end{array}$ & $\begin{array}{l}\text { Aug. } \\
7-8\end{array}$ \\
\hline A & $\begin{array}{cc}\text { Model } & 1 \\
\text { " } & 2 \\
\text { " } & 3 \\
\text { " } & 4 \\
\end{array}$ & $\begin{array}{r}-13.1 \\
2.9 \\
7.1 \\
-33.9 \\
\end{array}$ & $\begin{array}{r}-14.4 \\
-2.3 \\
1.0 \\
-37.8 \\
\end{array}$ & $\begin{array}{r}-33.0 \\
-7.8 \\
-1.0 \\
-69.7 \\
\end{array}$ & $\begin{array}{r}-33.7 \\
-4.7 \\
3.0 \\
-69.1 \\
\end{array}$ & $\begin{array}{r}-36.5 \\
-7.9 \\
-0.1 \\
-78.3 \\
\end{array}$ \\
\hline B & $\begin{array}{cc}\text { Model } & 1 \\
\text { " } & 2 \\
\text { " } & 3 \\
\text { " } & 4 \\
\end{array}$ & $\begin{array}{r}-19.3 \\
-6.5 \\
-0.5 \\
-30.5 \\
\end{array}$ & $\begin{array}{r}-6.1 \\
0.9 \\
3.3 \\
-21.6 \\
\end{array}$ & $\begin{array}{r}-28.4 \\
-12.2 \\
-6.4 \\
-60.8 \\
\end{array}$ & $\begin{array}{r}-28.4 \\
-11.3 \\
-4.7 \\
-58.0 \\
\end{array}$ & $\begin{array}{r}-30.2 \\
-13.2 \\
-6.9 \\
-64.7 \\
\end{array}$ \\
\hline \multicolumn{7}{|c|}{ Average Residual $=(1 / \mathrm{N}) \Sigma \Delta \mathrm{C}=\overline{\Delta \mathrm{C}}$} \\
\hline Model & \multicolumn{2}{|c|}{ Site A } & \multicolumn{2}{|c|}{ Site B } & \multicolumn{2}{|c|}{ Both sites } \\
\hline $\begin{array}{l}1 \\
2 \\
3 \\
4 \\
\end{array}$ & \multicolumn{2}{|c|}{$\begin{array}{r}-26.14 \\
-3.96 \\
2.00 \\
-57.76 \\
\end{array}$} & \multicolumn{2}{|c|}{$\begin{array}{r}-22.48 \\
-8.46 \\
-3.04 \\
-47.12 \\
\end{array}$} & \multicolumn{2}{|c|}{$\begin{array}{r}-24.31 \\
-6.21 \\
-0.52 \\
-52.44 \\
\end{array}$} \\
\hline \multicolumn{7}{|c|}{ Average $\mathrm{Ab}$} \\
\hline Model & \multicolumn{2}{|c|}{ Site A } & \multicolumn{2}{|c|}{ Site B } & \multicolumn{2}{|c|}{ Both sites } \\
\hline $\begin{array}{l}1 \\
2 \\
3 \\
4 \\
\end{array}$ & \multicolumn{2}{|c|}{$\begin{array}{r}26.14 \\
5.12 \\
2.44 \\
57.76 \\
\end{array}$} & \multicolumn{2}{|c|}{$\begin{array}{r}22.48 \\
8.82 \\
4.36 \\
47.12 \\
\end{array}$} & \multicolumn{2}{|c|}{$\begin{array}{r}24.31 \\
6.97 \\
3.40 \\
52.44 \\
\end{array}$} \\
\hline \multicolumn{7}{|c|}{$\overline{c_{0}}-\overline{|\Delta c|}$} \\
\hline Model & \multicolumn{2}{|c|}{ Site $A$} & \multicolumn{2}{|l|}{ Site B } & \multicolumn{2}{|c|}{ Both sites } \\
\hline $\begin{array}{l}1 \\
2 \\
3 \\
4\end{array}$ & \multicolumn{2}{|c|}{$\begin{array}{r}-17.14 \\
3.88 \\
6.56 \\
-48.76 \\
\end{array}$} & \multicolumn{2}{|c|}{$\begin{array}{r}-18.48 \\
-4.82 \\
-0.36 \\
-43.12 \\
\end{array}$} & \multicolumn{2}{|c|}{$\begin{array}{r}-17.81 \\
-0.47 \\
3.10 \\
-45.94 \\
\end{array}$} \\
\hline
\end{tabular}


TABLE 12 (Continued)

\begin{tabular}{|c|c|c|c|}
\hline \multicolumn{4}{|c|}{ Average Percent Error } \\
\hline & $\begin{array}{c}\text { Concentration } \\
\text { Average }\end{array}$ & $\frac{\text { Model - Measured }}{\text { Measured }}$ & $\times 100 \%$ \\
\hline \begin{tabular}{cc}
\multicolumn{2}{c}{ Measured } \\
Model & 1 \\
" & 2 \\
" & 3 \\
" & 4
\end{tabular} & $\begin{array}{r}6.5 \\
30.8 \\
12.8 \\
7.0 \\
59.0\end{array}$ & $\begin{array}{r}- \\
374 \\
97 \\
8 \\
808\end{array}$ & \\
\hline $\begin{array}{l}{ }^{1} \text { Concentra } \\
\text { summing }\end{array}$ & $\begin{array}{l}\text { on average is a } \\
\text { sites. }\end{array}$ & day average, & \\
\hline
\end{tabular}

Model precision, the deviation within the data set, is assessed using the performance measures calculated in Table 13.

TABLE 13: Model Precision at BKK (Concentrations in ppb)

\begin{tabular}{|c|c|c|c|}
\hline \multicolumn{4}{|c|}{ Noise $=\left\langle[1 /(N-1)] \Sigma[\Delta C-\overline{\Delta C}]^{2}\right\rangle^{1 / 2}$} \\
\hline Model & Site A & Site B & Both sites \\
\hline $\begin{array}{l}1 \\
2 \\
3 \\
4\end{array}$ & $\begin{array}{r}11.4 \\
4.5 \\
3.2 \\
20.4\end{array}$ & $\begin{array}{r}10.1 \\
5.8 \\
4.3 \\
19.6\end{array}$ & $\begin{array}{r}10.2 \\
4.9 \\
3.6 \\
18.8\end{array}$ \\
\hline \multicolumn{4}{|c|}{ Gross Error $=\left\langle[1 /(N-1)] \Sigma[\Delta C]^{2}\right\rangle^{1 / 2}$} \\
\hline Model & Site $A$ & Site B & Both sites \\
\hline $\begin{array}{l}1 \\
2 \\
3 \\
4\end{array}$ & $\begin{array}{r}31.4 \\
6.3 \\
3.9 \\
67.7\end{array}$ & $\begin{array}{r}27.1 \\
11.1 \\
5.5 \\
56.2 \\
\end{array}$ & $\begin{array}{r}27.6 \\
8.5 \\
4.5 \\
58.7 \\
\end{array}$ \\
\hline
\end{tabular}


The linear regression and Pearson correlation coefficient for the four screening models are presented in Table 14, with sites $A$ and $B$ analyzed separately and together.

TABLE 14: Linear Regression and Pearson Correlation Coefficient at BKK

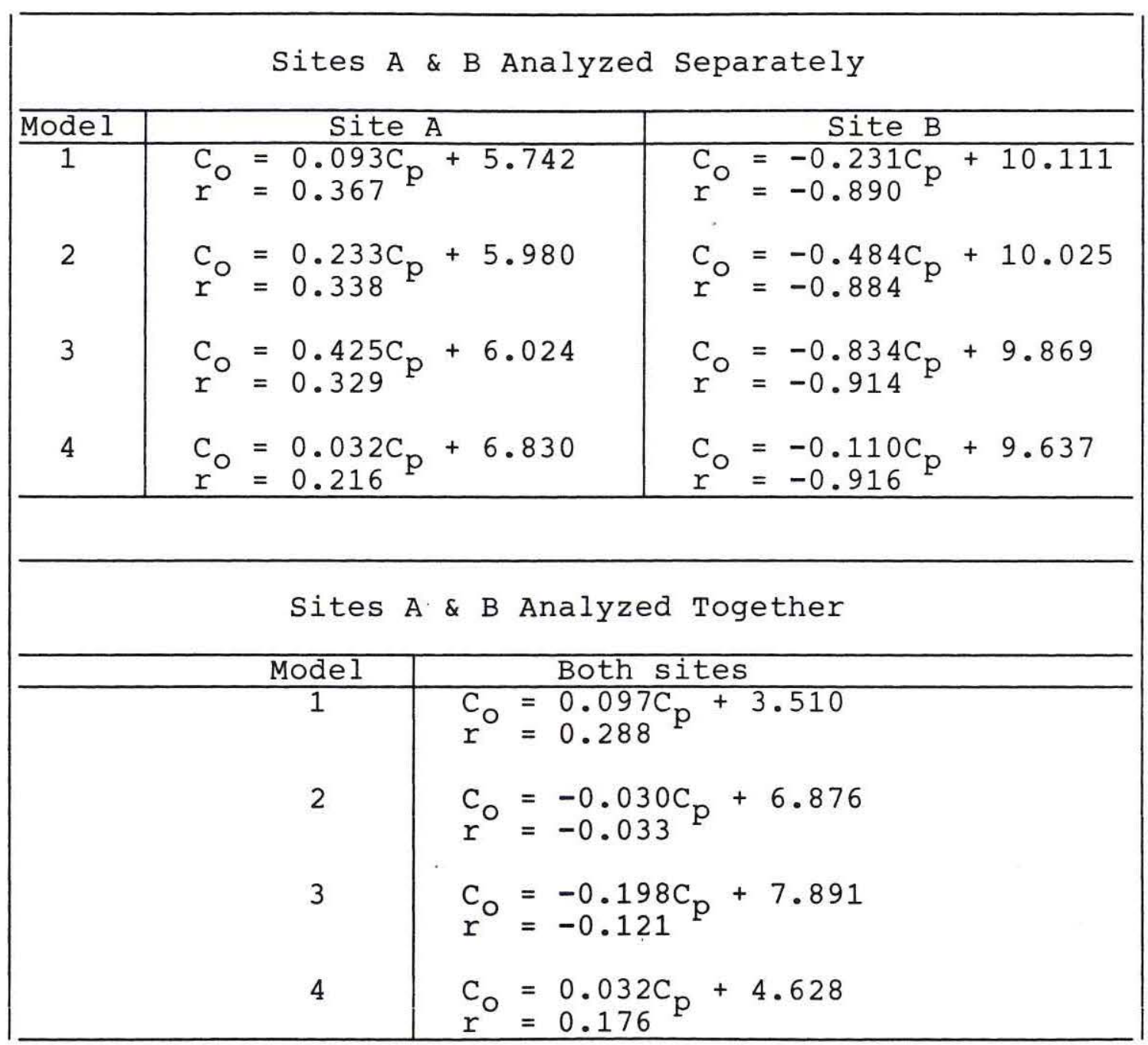

Table 12 shows that model 2 and especially model 3 have the smallest residuals and percent errors. Similarly, Table 13 shows that models 2 and 3 are most precise.

Table 12 also shows that all four models overestimate 
concentrations and are, thus, biased. With respect to health and air quality standards, screening models should be conservative. Hence, overestimating concentrations is a desirable screening model attribute. Table 8 shows that on a daily basis, models 2 and 3 appear unbiased at sites $A$ and B, as both models under and overestimated concentrations. However, the data set is too small to conclude this with much confidence.

The significance of the correlation coefficients was calculated using (12) from Till (1974), with (n - 2) degrees of freedom:

$$
t=r \sqrt{\frac{n-2}{1-r^{2}}} .
$$

The significance level for rejecting a null hypothesis of $r=0$ was between 0.05 and 0.10 . 
CHAPTER 5

\section{Summary and Conclusions}

Four air pollution screening models estimated the ambient air concentration of vinyl chloride downwind of the BKK Landfill. The emission rate of vinyl chloride was first estimated using parameters which included the concentration of vinyl chloride in landfill gas, the depth of the soil landfill cover, soil porosity, and the portion of the hilly landfill impacting two residential monitoring sites under different wind patterns. Wind and atmospheric stability conditions at BKK were estimated using hourly meteorological data from the Ontario International Airport. The screening models were evaluated by comparing model estimates with measured vinyl chloride concentrations. Model 3, a virtual point source model (U.S. EPA, 1981), closely estimated measured vinyl chloride concentrations, with an average error of $8 \%$, and is recommended for assessing ambient organic chemical concentrations in addition to vinyl chloride downwind of landfills prior to making a decision to monitor concentrations or conduct more detailed modeling.

Due to the lack of measurements of some emission rate input variables, these variables were approximated using background information. Approximating input data can result in errors in concentration estimates, in this case ranging from -113 to $237 \%$ of the concentrations used in the model 
evaluation.

The poor performance of models 1 and 4 was not caused only by approximating input data. Model 1 (Shen, 1982) was designed for estimating dispersion from a ground level point source rather than an area source. Model 4, the simple box model (Gifford and Hanna, 1970), was designed for long term averages from an urban area source (and has performed well in urban area applications according to sedefian, no date) and would not be expected to perform as accurately for a smaller area source such as a landfill. Model 4 also uses neutral stability for 24 hour averages and does not allow for varying stability on an hourly basis to match changing meteorological conditions. Hence, models 1 and 4 are not recommended for use with landfills. Models 2 (Turner, 1969) and 3 , both virtual point source models, contain appropriate parameters for estimating dispersion from a small area source such as a landfill, so it was not surprising that these two models performed better than models 1 and 4 . Models 2 and 3 should be further evaluated with monitoring data from a small, flat landfill for which information on the landfill chemical waste, landfill cover, landfill temperature, and on-site meteorological data are available. Proper siting of monitoring and meteorological instruments is critical in collecting representative data (Finkelstein et al., 1983). An evaluation based on concentrations of a chemical with a vapor pressure below 1 atm 
would allow comparison of the emission rate equations, (2) and (4). With proper data, both of these emission rate equations could be compared with the equation of Farmer et al. (1980) for estimating the migration of landfill gases to the surface.

Emission rate equations should be revised to include additional input parameters to improve simulation of the landfill emission process. Emission rate equations (2) and (4) have few common parameters. Neither (2) nor (4) include the effects of soil moisture, solubility of volatile organic chemical waste in soil moisture, infiltration, or wind. 
Arjaratman, A., 1984: Personal communication. BKK Landfill, West Covina, CA.

CA DOHS, 1983: Ambient Air Monitoring and Health Risk Assessment for Suspect Human Carcinogens Around the BKK Landfill in West Covina. California Dept. of Health Services (Toxic Substances Control Division), California Air Resources Board (Haagen-Smit Laboratory Division), South Coast Air Quality Management District.

CA SWMB, 1978: Minimum Standards for Solid Waste Handling and Disposal. Title 14, Ch. 3, Register 78, No. 33 $8 / 19 / 78$, Section 17225.16. California Solid Waste Management Board.

CARB, 1982: Public Meeting to Discuss an Assessment of the Volatile and Toxic Organic Emissions from Hazardous Waste Disposal in California. California Air Resources Board, Sacramento, CA.

CARB, 1982: A Suggested Control Measure to Reduce Organic Compound Emissions Associated with Volatile Organic Waste Disposal. California Air Resources Board, Sacramento, $\mathrm{CA}$.

CRC, 1984: CRC Handbook of Chemistry and Physics. 19841985, 65th Edition. R.C. Weast, editor. CRC Press, Inc., Boca Raton, FL.

Dobbs, A.J. and M.R. Cull, 1982: Volatilisation of Chemicals - Relative Loss Rates and the Estimation of Vapour Pressures. Envir. Pollution (Series B)., 3 , $289-298$.

Farmer, W., Yang, M.S., Letey, J., 1980: Land Disposal of Hexachlorobenzene Wastes - Controlling Vapor Movement in Soil. U.S. EPA. Report No. 600/2-80-119.

Farmer, W., 1984: Personal communication. Dept. of Soil \& Environmental Sciences, UC Riverside, CA.

Finkelstein, P.L., Mazzarella, D.A., Lockhart, T.J., King, w.J., White, J.H., 1983: Quality Assurance Handbook for Air Pollution Measurement Systems - Volume IV, Meteorological Measurements. U.S. EPA. Report No. 600/4-82-060. 
Freas, W.P. and R.F. Lee, 1976: Sensitivity Analysis of the Single Source (CRSTER) Model. Presented at Seventh International Technical Meeting on Air Pollution Modeling and Its Application. Published in U.S. EPA. Report No. 450/2-77-013.

Gifford, F.A. and S.R. Hanna, 1970: Urban Air Pollution Modelling. Proceedings of the Second International Clean Air Congress. Dec. 6-11, 1970. Edited by H.M. Englund and W.T. Beery. Washington, D.C.

Hayes, S.R., 1979: Performance Measures and Standards for Air Quality Simulation Models. U.S. EPA. Report No. 450/4-79-032.

Keith, R.W., 1980: A Climatological/Air Quality Profile California South Coast Air Basin. South Coast Air Quality Management District, El Monte, CA.

NOAA, 1984: Daily Weather Maps. Weekly Series. National Oceanic and Atmospheric Administration, National Weather Service, National Meteorological Center, Climate Analysis Center.

Novak, J. and D.B. Turner, 1976: An Efficient GaussianPlume Multiple Source Air Quality Algorithm. J. Air Poll. Control Assoc., 26, 570-575.

Pearl, E.H., 1984: Personal communication. Dept. of Environmental Studies, San Jose State Univ., CA.

Raygor, S.C., 1973: Microbiological Air Pollution from a Sewage Treatment Plant Aeration Tank. Masters Thesis. Dept. of Meteorology, San Jose State Univ., CA.

Riggin, R.M., 1983: Technical Assistance Document for Sampling and Analysis of Toxic Organic Compounds in Ambient Air. Battelle-Columbus Laboratories, Columbus, Ohio.

, 1984: Compendium of Methods for the Determination of Toxic Organic Compounds in Ambient Air. U.S. EPA. Report No. 600/4-84-041.

Rose, H., 1984: Personal communication and SCAQMD data regarding BKK. South Coast Air Quality Management District, El Monte, CA.

Rovers, F.A. and G.J. Farquhar, 1973: Infiltration and Landfill Behavior. J. of the Envir. Engineering Division, ASCE. , 99, 671-690. 
SCAQMD, 1982: Vinyl Chloride in the South Coast Basin. South Coast Air Quality Management District, El Monte, CA.

SCAQMD, 1984: Source Test Report at BKK. March 9, 1984. South Coast Air Quality Management District.

Sedefian, L., no date: Screening Procedures for Determining Ambient Impacts of Toxic Contaminants. New York Dept. of Environmental Conservation, Albany, NY.

Shen, T., 1981: Control Techniques for Gas Emissions from Hazardous Waste Landfills. J. Air Poll. Control Assoc., 31, 132-135.

- 1982: Air Quality Assessment for Land Disposal of Industrial Wastes. Envir. Mgmt., $\underline{6}$, 297-305.

Slade, D., 1968: Meteorology and Atomic Energy. U.S. Atomic Energy Commission.

Terzaghi, K. and R.B. Peck, 1967: Soil Mechanics in Engineering Practice. John Wiley \& Sons, New York, NY.

Thibodeaux, L.J., 1981: Estimating the Air Emissions of Chemicals from Hazardous Waste Landfills. J. of Hazardous Materials., $\underline{4}, 235-244$.

Thibodeaux, L.J., Springer, C., Riley, L.M., 1982: Models of Mechanisms for the Vapor Phase Emissions of Hazardous Chemicals from Landfills. J. of Hazardous Materials., $\underline{7}, 63-74$.

Thibodeaux, L.J., Hildebrand, G., Springer, C., 1984: A Pilot Scale Study of Volatile Organic Emissions from Hazardous Waste Landfills. Presented at the Air Pollution Control Association Annual Meeting, San Francisco, CA.

Thibodeaux, L.J., 1984: Personal communication. Dept. of Chemical Engineering, Univ. of Arkansas.

Tikvart, J.A. and W.M. Cox, 1984: EPA's Model Evaluation Program. Presented at the Fourth Joint Conference on Applications of Air Pollution Meteorology, Portland, OR.

Till, R., 1974: Statistical Methods for the Earth Scientist - An Introduction. Halsted Press. John Wiley \& Sons, New York, NY. 
Turner, D.B., 1969: Workbook of Atmospheric Dispersion Estimates. U.S. Public Health Service.

1976: A Climatological Disperison Model for $10^{\circ}$ Wind Sectors. Submitted to the NATO/CCMS Panel of Modeling.

U.S. EPA, 1981: Evaluation Guidelines for Toxic Air Emissions from Land Disposal Facilities. U.S. EPA, office of Solid Waste, Washington, D.C.

Weast, R.C., 1984: Personal communication. Editor, CRC Handbook of Chemistry and Physics. CRC Press, Inc., Boca Raton, FL. 


\section{APPENDIX A}

\section{Ontario International Airport Meteorological Data (1984)}

Used in the BKK Analysis

Appendix A contains the hourly wind speed, direction, and atmospheric stability data used in the BKK analysis. The meteorological data are presented to correspond with the monitoring data collection period, which was from 10:00 a.m. (LT) to 10:00 a.m. the following day. 


\begin{tabular}{|c|c|c|c|c|c|c|c|c|c|c|}
\hline & \multicolumn{2}{|c|}{ Mar. $7-8$} & \multicolumn{2}{|c|}{ Mar. 8-9 } & \multicolumn{2}{|c|}{ Aug. 5-6 } & \multicolumn{2}{|c|}{ Aug. $6-7$} & \multicolumn{2}{|c|}{ Aug. $7-8$} \\
\hline$\overline{\text { Hour (LT) }}$ & Wind & Stab & Wind & Stab & Wind & stab & Wind & Stab & Wind & Stab \\
\hline 10:00am & 1305 & B & 0604 & $\bar{A}$ & 2105 & B & 0000 & $\bar{A}$ & 2505 & $\mathrm{~A}$ \\
\hline $11: 00 \mathrm{am}$ & 0000 & $\bar{A}$ & 2103 & $\bar{A}$ & 2206 & $\bar{A}$ & 2305 & $\bar{A}$ & 1905 & $\bar{A}$ \\
\hline $12: 00 \mathrm{~N}$ & 1904 & $\bar{A}$ & 2407 & $\bar{A}$ & 2506 & $\bar{A}$ & 2406 & $\bar{A}$ & 2307 & A \\
\hline $1: 00 \mathrm{pm}$ & 1808 & $\bar{A}$ & 2709 & $\bar{A}$ & 2209 & $\bar{A}$ & 2109 & $\bar{A}$ & 2109 & $\bar{A}$ \\
\hline $2: 00 \mathrm{pm}$ & 2506 & $\bar{A}$ & 2810 & $\mathrm{~B}$ & 2208 & $\bar{A}$ & 2310 & $\bar{A}$ & 2310 & $\mathrm{~B}$ \\
\hline $3: 00 \mathrm{pm}$ & 2210 & $\bar{B}$ & 2408 & $\bar{A}$ & 2107 & $\bar{A}$ & 2212 & B & 2212 & $\mathrm{~B}$ \\
\hline $4: 00 \mathrm{pm}$ & 2510 & B & 2410 & $\bar{B}$ & 2314 & B & 2215 & $\bar{B}$ & 2313 & $\mathrm{~B}$ \\
\hline $5: 00 \mathrm{pm}$ & 2410 & B & 2310 & $\mathrm{C}$ & 2313 & B & 2315 & B & 2316 & B \\
\hline $6: 00 \mathrm{pm}$ & 2610 & $\mathrm{C}$ & 2808 & C & 2215 & $\mathrm{C}$ & 2112 & $\mathrm{C}$ & 2215 & C \\
\hline $7: 00 \mathrm{pm}$ & 2407 & $\bar{D}$ & 2510 & $\bar{D}$ & 2013 & $\bar{C}$ & 2114 & $\mathrm{C}$ & 2312 & $\mathrm{C}$ \\
\hline $8: 00 \mathrm{pm}$ & 2705 & D & 2506 & D & 2011 & D & 2010 & D & 2210 & D \\
\hline $9: 00 \mathrm{pm}$ & 1105 & D & 2506 & D & 2110 & D & 2009 & D & 1806 & D \\
\hline $10: 00 \mathrm{pm}$ & 0000 & D & 1504 & D & 2209 & D & 1905 & $\bar{D}$ & 2208 & D \\
\hline $11: 00 \mathrm{pm}$ & 0000 & $\bar{D}$ & 0104 & $\bar{D}$ & 2308 & $\bar{D}$ & 2505 & $\bar{D}$ & 0000 & $\bar{D}$ \\
\hline $12: 00 \mathrm{mid}$ & 0105 & $\bar{D}$ & 0000 & D & 2005 & D & 0000 & D & 0000 & D \\
\hline $1: 00 \mathrm{am}$ & 0105 & D & 0305 & $\bar{D}$ & 0000 & D & 0000 & D & 0000 & D \\
\hline 2:00am & 0000 & $\bar{D}$ & 3604 & $\bar{D}$ & 0000 & $\mathrm{D}$ & 0000 & $\mathrm{D}$ & 0000 & D \\
\hline $3: 00 a m$ & 0105 & $\bar{D}$ & 0305 & $\bar{D}$ & 0000 & $\bar{D}$ & 0000 & $\bar{D}$ & 0000 & D \\
\hline $4: 00 a m$ & 0105 & $\bar{D}$ & 3605 & D & 0000 & D & 0000 & D & 0000 & $\bar{D}$ \\
\hline $5: 00 \mathrm{am}$ & 3505 & D & 3605 & $\bar{D}$ & 0000 & $\bar{D}$ & 0000 & D & 3605 & D \\
\hline $6: 00 a m$ & 0205 & $\mathrm{D}$ & 3604 & $\mathrm{D}$ & 0000 & D & 0000 & $\mathrm{D}$ & 3505 & D \\
\hline $7: 00 \mathrm{am}$ & 0105 & B & 0000 & B & 0000 & D & 3505 & B & 3504 & B \\
\hline $8: 00 a m$ & 0404 & B & 2505 & B & 1105 & $B$ & 1905 & B & 3503 & B \\
\hline $9: 00 a m$ & 0000 & $\bar{A}$ & 2505 & $B$ & 0000 & $B$ & 0000 & $B$ & 1604 & $B$ \\
\hline
\end{tabular}

Key

Wind $(X X Y Y): \quad X X=$ Direction in $10 \mathrm{~s}$ of degrees

$Y Y=$ Speed in $\operatorname{knots}$ ( $\operatorname{rnots} / 2=\mathrm{m} / \mathrm{s}$, approx.)

Stab: Stability class (Turner, 1976)

(Airport elevation is 950 feet above sea level; met. instruments are 3 meters above ground.) 


\author{
APPENDIX B \\ Daily Weather Maps Coinciding with \\ the BKK Analysis
}

Appendix B contains daily weather maps for the five sampling periods used in the BKK analysis (NOAA, 1984). For each date, a surface weather map and a 500-millibar height contour map are presented. 
WEDNESDAY, MARCH 7, 1984
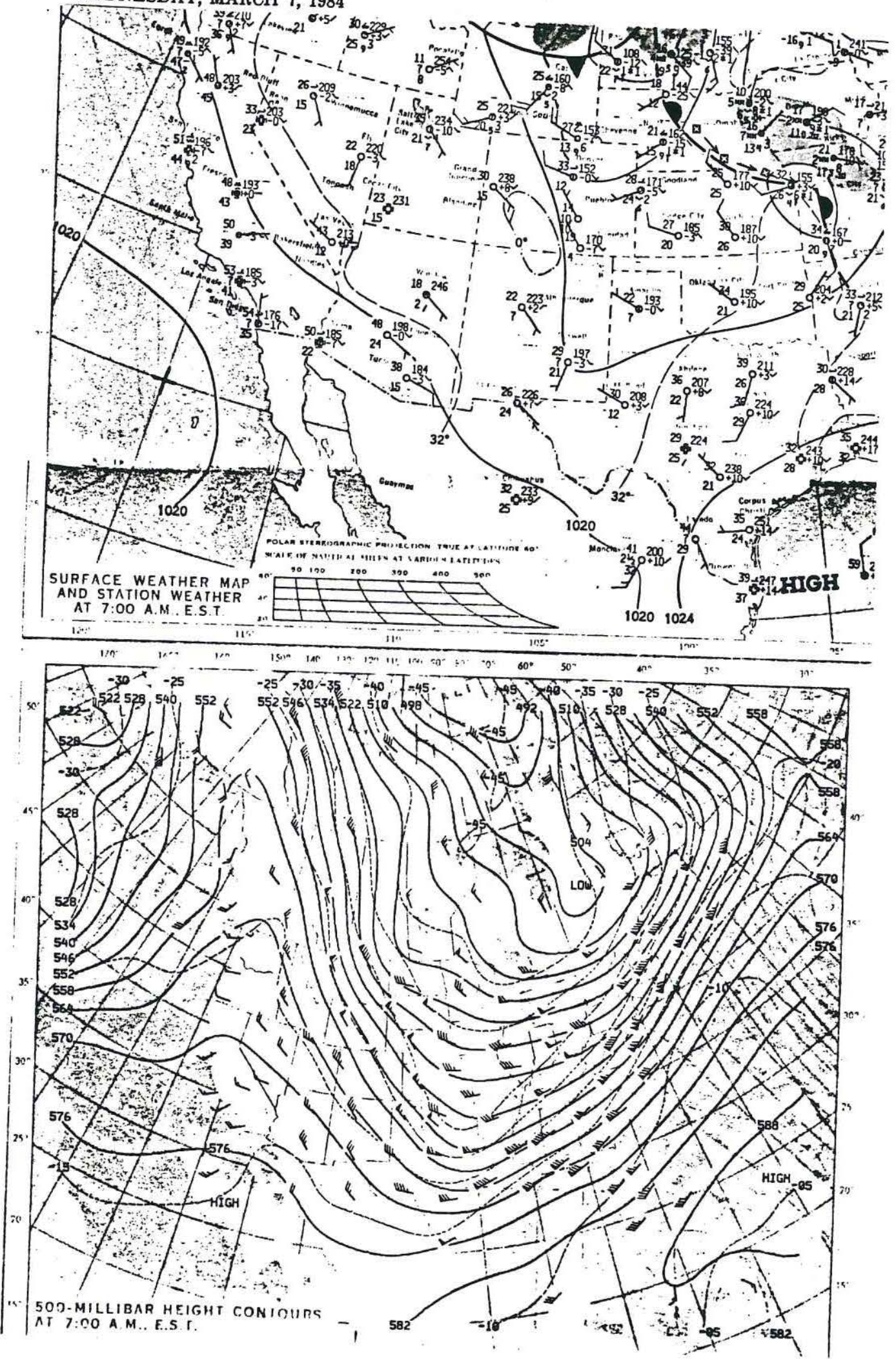
THURSDAY, MARCH 8, 1984
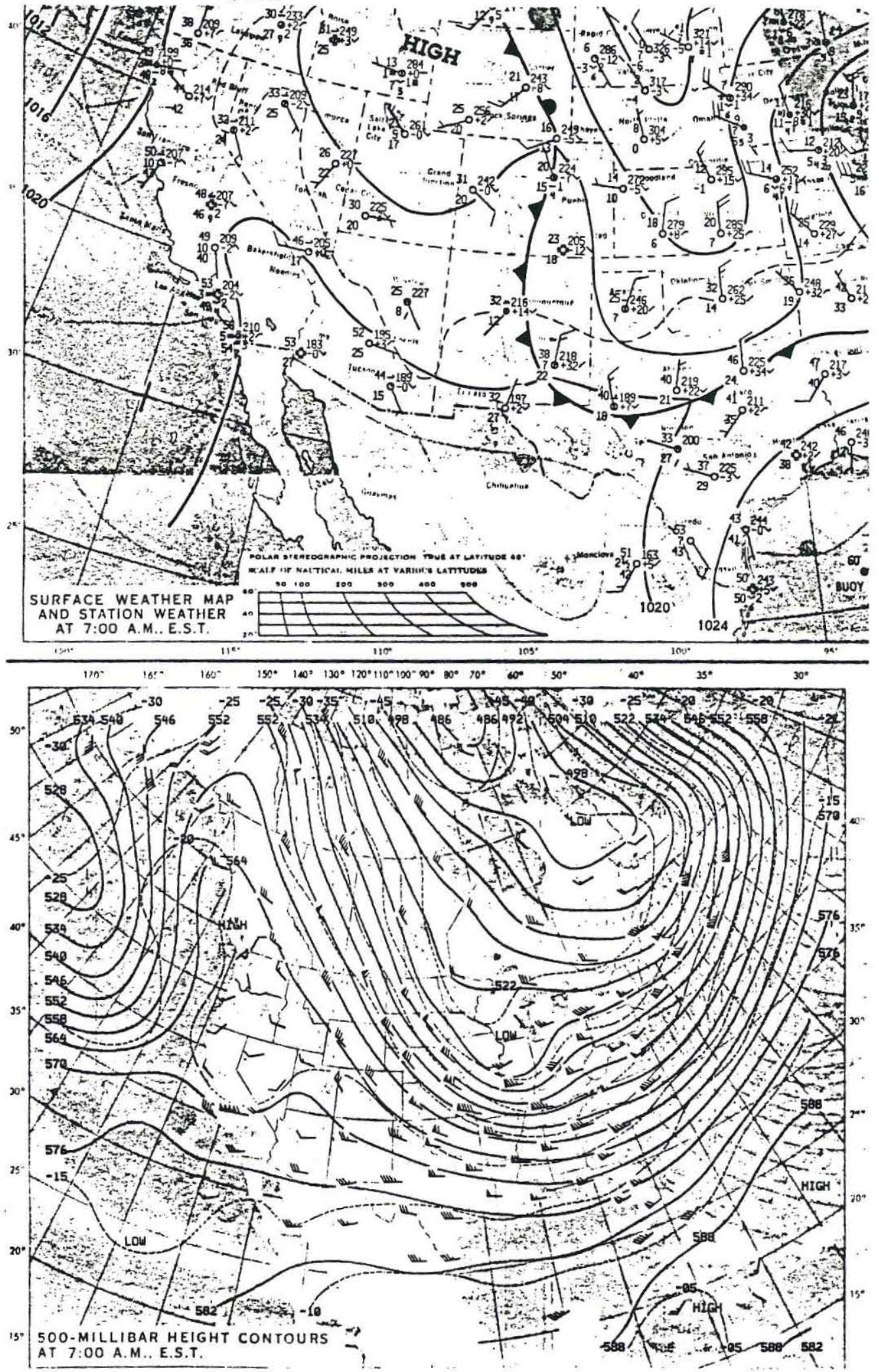
FRIDAY, MARCH 9, 1984
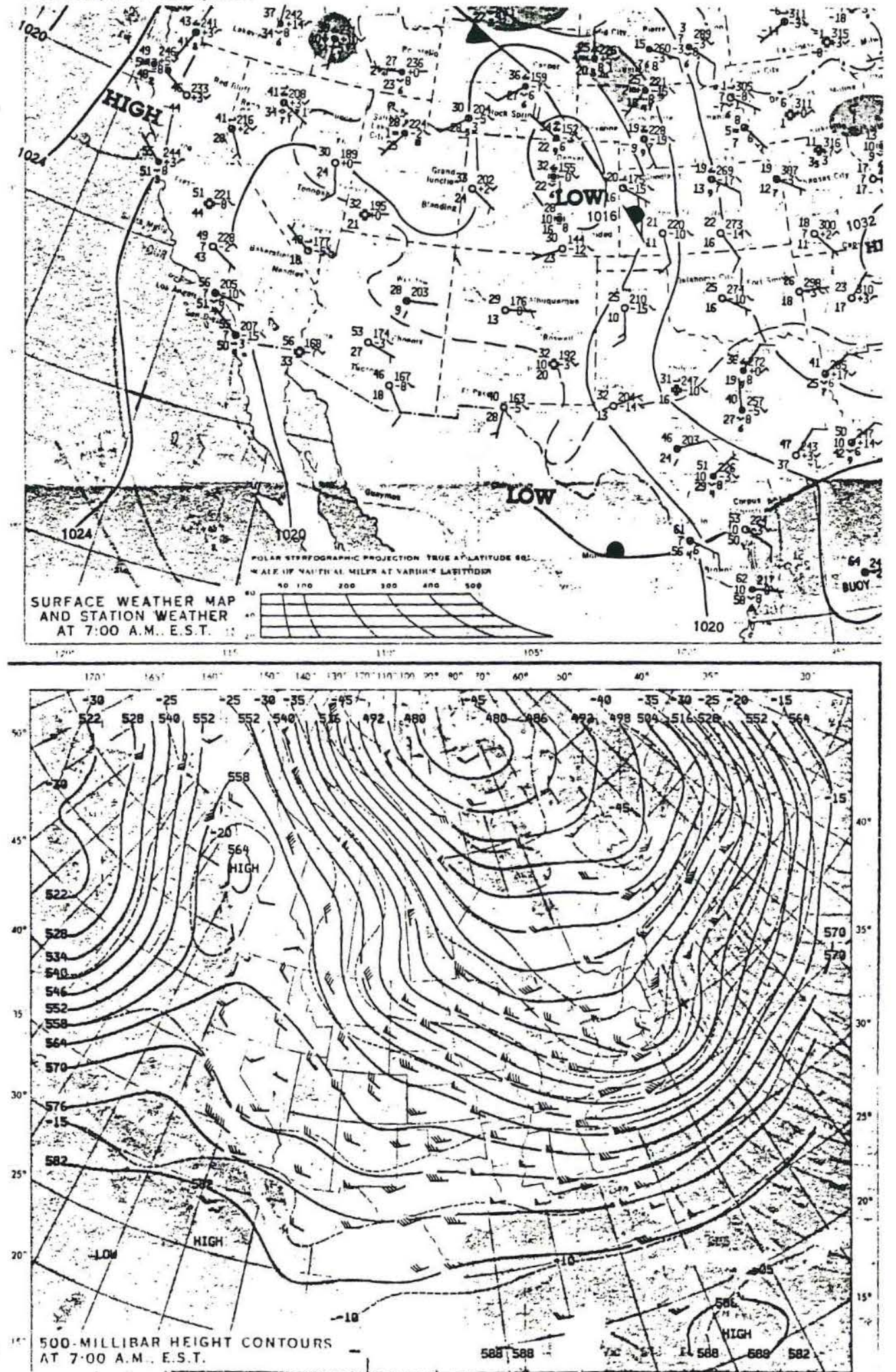

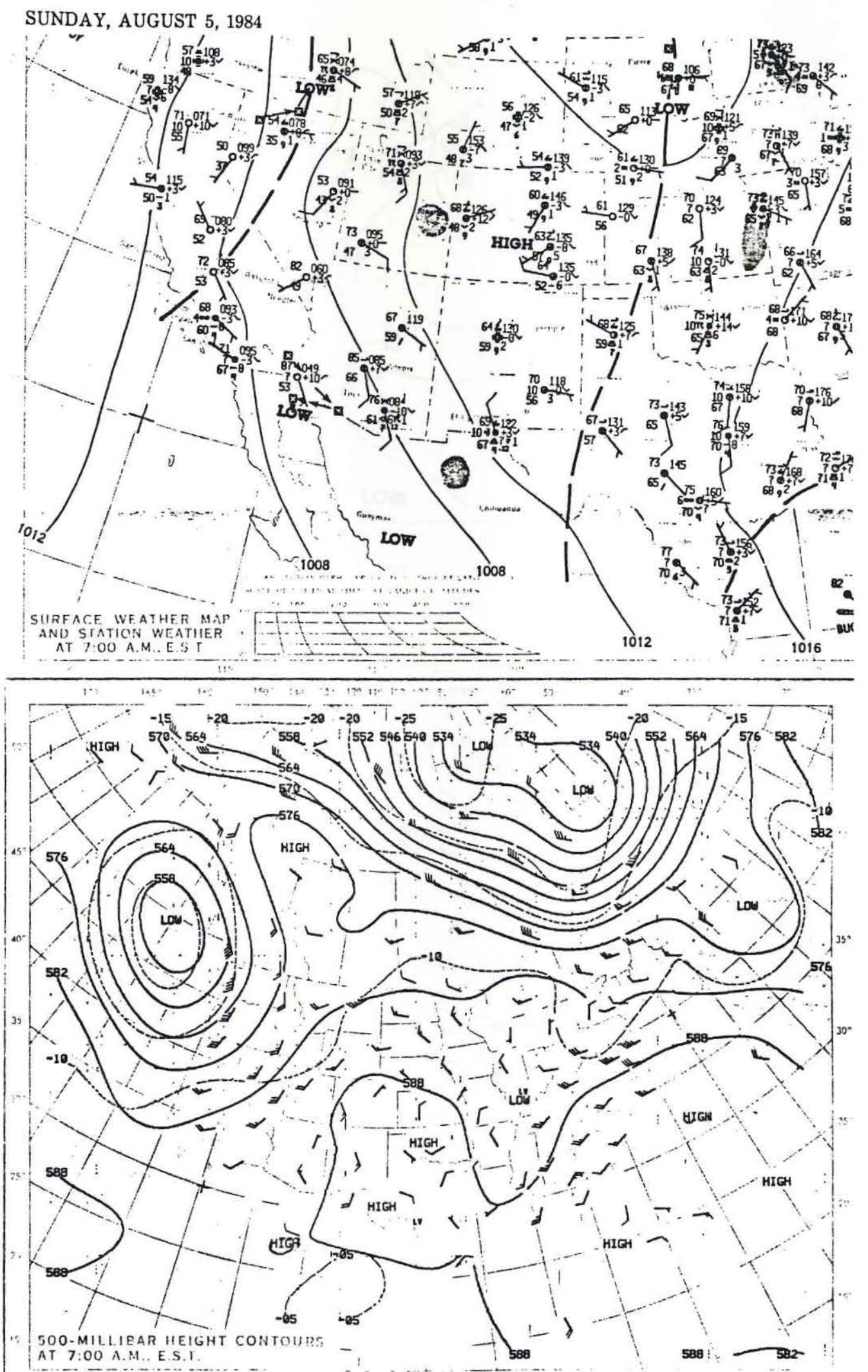


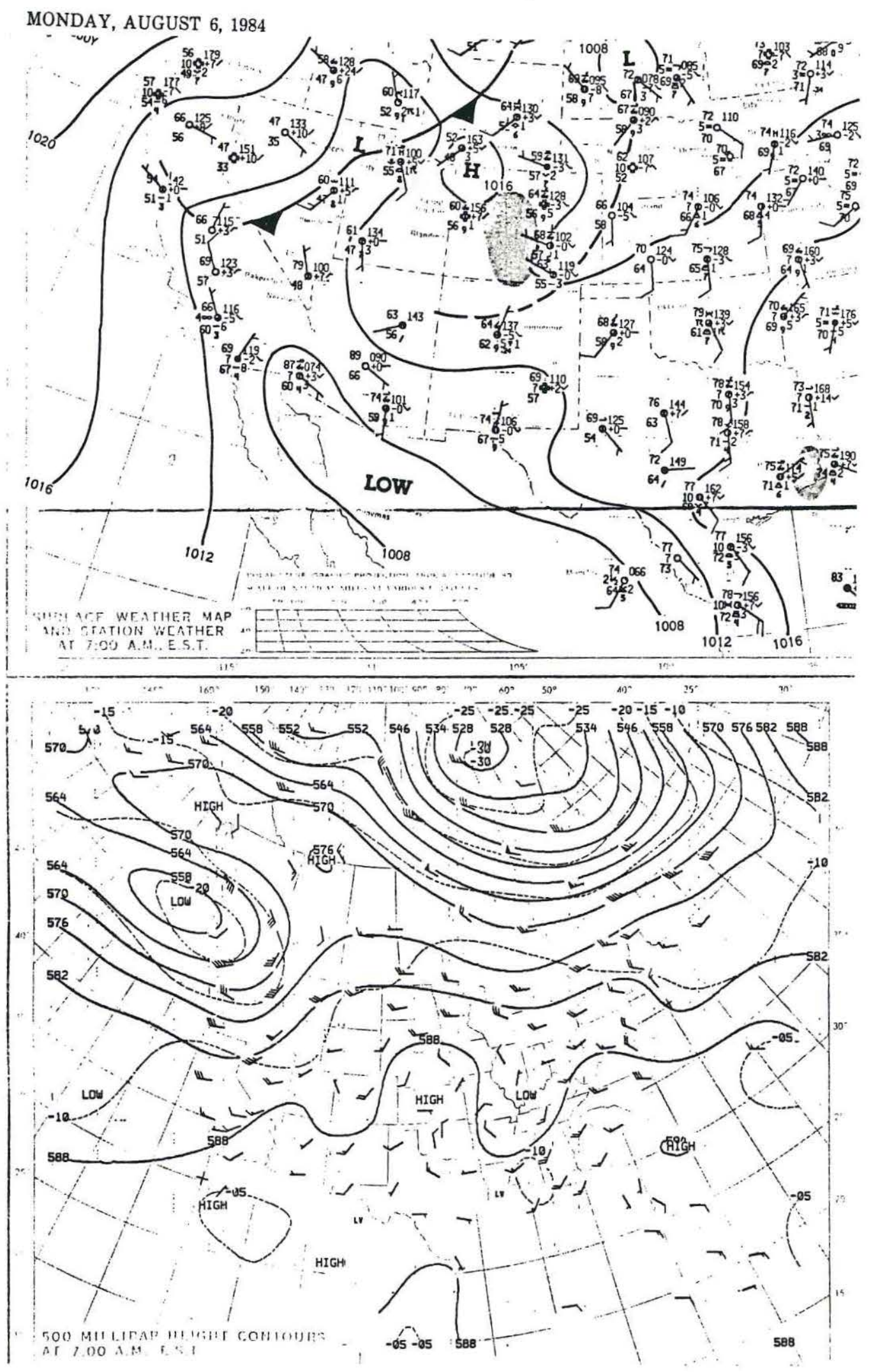


TUESDAY, AUGUST 7, 1984
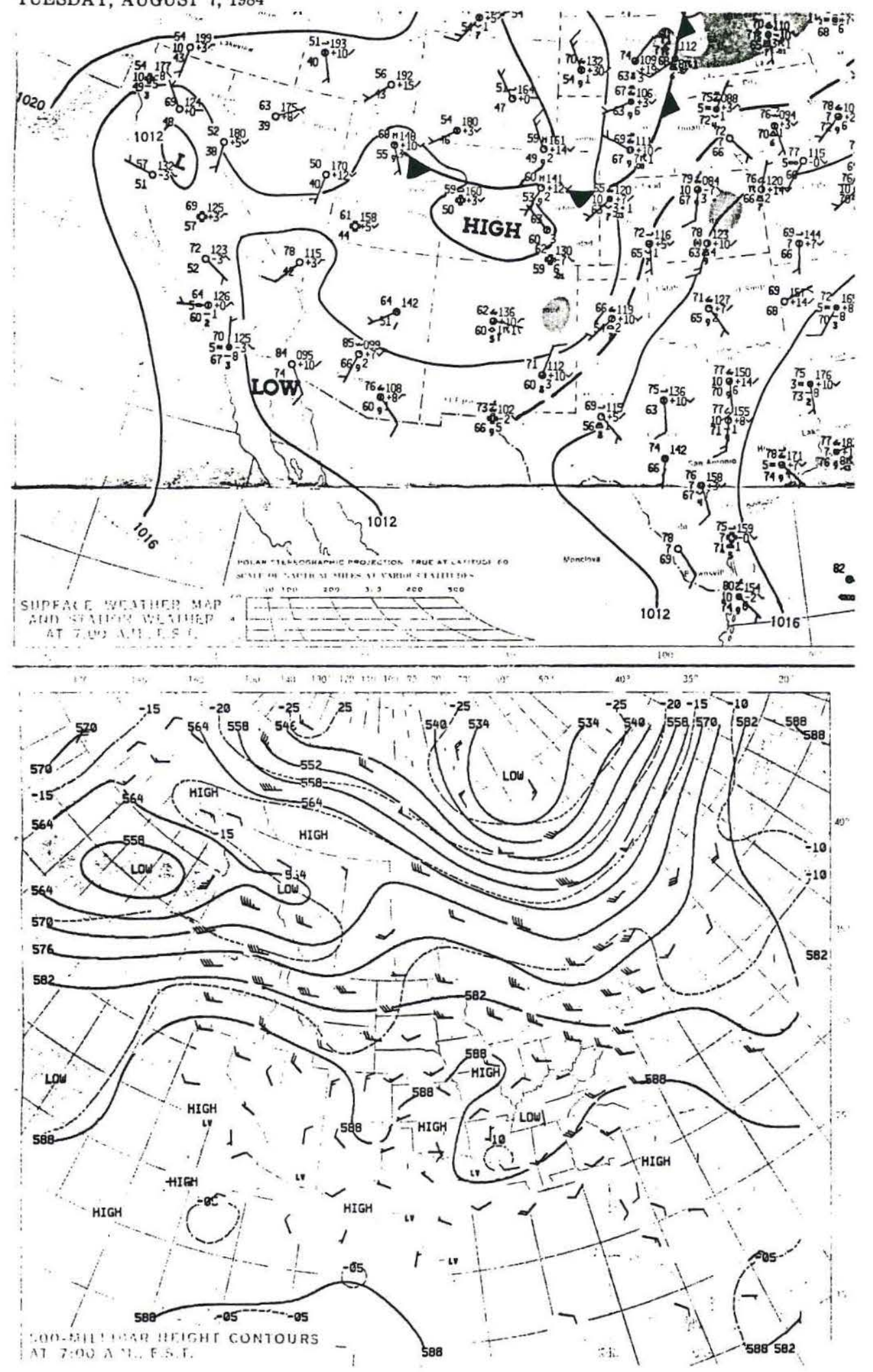

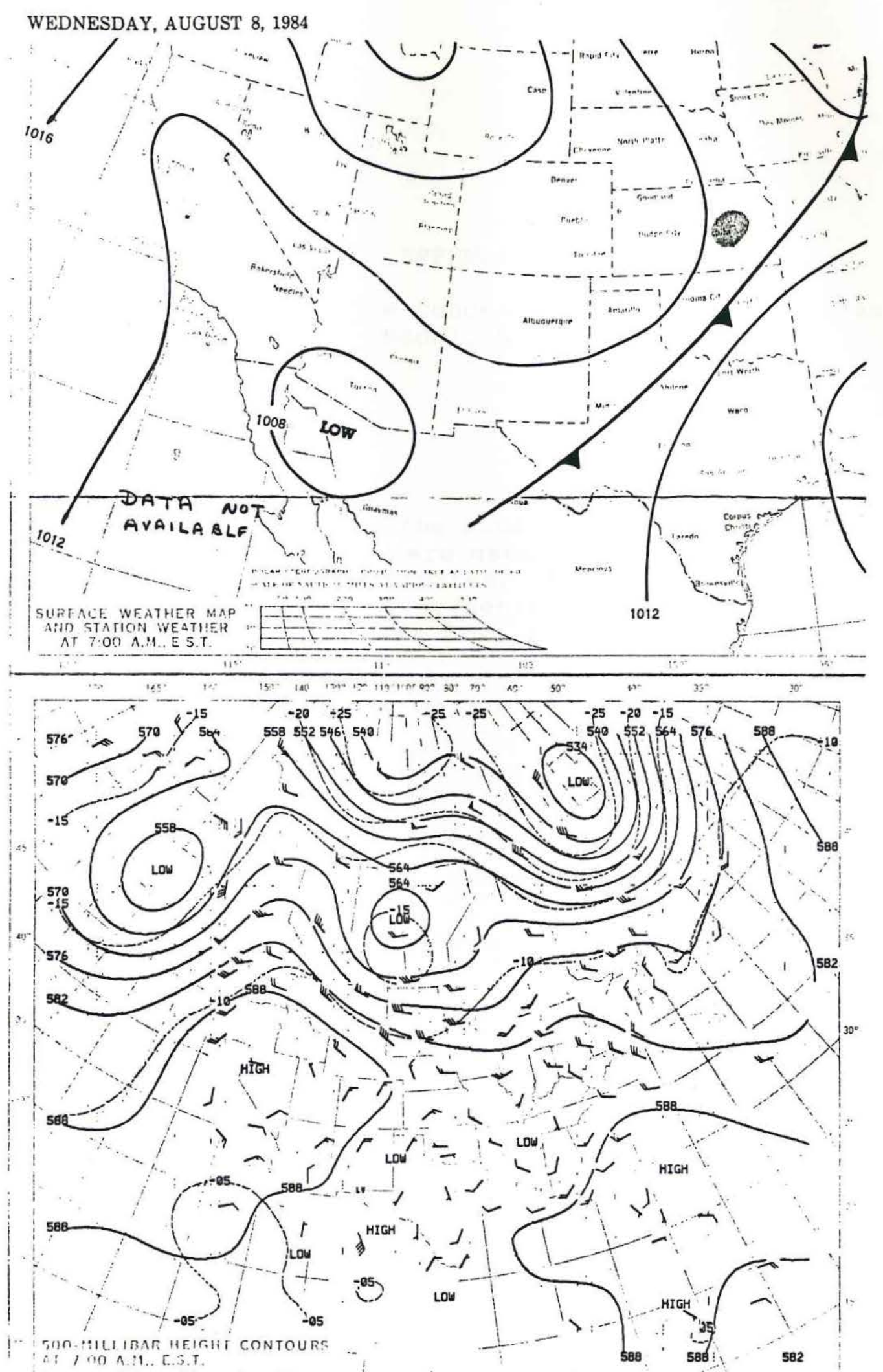


\section{APPENDIX C}

Hourly Vinyl Chloride Concentration (ppb) Estimates at BKK by Model, Site, and Date

Appendix C contains the hourly vinyl chloride concentration estimates which were used in calculating the 24 hour average concentration estimates. As in Appendix A, the hourly concentrations are presented to correspond to the sampling period, which was from 10:00 a.m. (LT) to 10:00 a.m. the following day. 
Model 1 (Shen, 1982)

\begin{tabular}{|c|c|c|c|c|c|c|c|c|c|c|}
\hline & \multicolumn{5}{|c|}{ Site A } & \multicolumn{5}{|c|}{ Site B } \\
\hline Hour (LT) & $\begin{array}{l}\text { Mar. } \\
7-8\end{array}$ & $\begin{array}{l}\text { Mar. } \\
8-9\end{array}$ & $\begin{array}{l}\text { Aug. } \\
5-6\end{array}$ & $\begin{array}{l}\text { Aug. } \\
6-7\end{array}$ & $\begin{array}{l}\text { Aug. } \\
7-8\end{array}$ & $\begin{array}{l}\text { Mar. } \\
7-8\end{array}$ & $\begin{array}{l}\text { Mar. } \\
8-9\end{array}$ & $\begin{array}{l}\text { Aug. } \\
5-6\end{array}$ & $\begin{array}{l}\text { Aug. } \\
6-7\end{array}$ & $\begin{array}{l}\text { Aug. } \\
7-8\end{array}$ \\
\hline $10: 00 \mathrm{am}$ & 0 & 0 & 0 & 0 & 0 & 0 & 0 & 0 & 0 & 0 \\
\hline $11: 00 \mathrm{am}$ & 0 & 0 & 0 & 0 & 0 & 0 & 0 & 0 & 0 & 0 \\
\hline $12: 00 \mathrm{~N}$ & $\overline{0}$ & 0 & 0 & 0 & 0 & 0 & 0 & 0 & 0 & 0 \\
\hline $1: 00 \mathrm{pm}$ & $\overline{0}$ & 1.4 & 0 & 0 & 0 & 0 & 0 & 0 & 0 & 0 \\
\hline $2: 00 \mathrm{pm}$ & 0 & 2.7 & 0 & 0 & 0 & 0 & 0 & 0 & 0 & 0 \\
\hline $3: 00 \mathrm{pm}$ & 0 & 0 & 0 & 0 & 0 & 0 & 0 & 0 & 0 & 0 \\
\hline $4: 00 \mathrm{pm}$ & 0 & 0 & 0 & 0 & 0 & 0 & 0 & 0 & 0 & 0 \\
\hline $5: 00 \mathrm{pm}$ & 0 & 0 & 0 & 0 & 0 & 0 & 0 & 0 & 0 & 0 \\
\hline $6: 00 \mathrm{pm}$ & 0 & 7.5 & 0 & 0 & 0 & 0 & 0 & 0 & 0 & 0 \\
\hline $7: 00 \mathrm{pm}$ & 0 & 0 & 0 & 0 & 0 & 0 & 0 & 0 & 0 & 0 \\
\hline $8: 00 \mathrm{pm}$ & 27 & 0 & 0 & 0 & 0 & 0 & 0 & 0 & 0 & 0 \\
\hline $9: 00 \mathrm{pm}$ & 0 & 0 & 0 & 0 & 0 & 181 & 0 & 0 & 0 & 0 \\
\hline $10: 00 \mathrm{pm}$ & 105 & 0 & 0 & 0 & 0 & 74 & 0 & 0 & 0 & 0 \\
\hline $11: 00 \mathrm{pm}$ & 105 & 53 & 0 & 0 & 155 & 74 & 37 & 0 & 0 & 110 \\
\hline $12: 00 \mathrm{mid}$ & 42 & 106 & 0 & 155 & 155 & 29 & 74 & 0 & 110 & 110 \\
\hline $1: 00 \mathrm{am}$ & 42 & 42 & 155 & 155 & 155 & 29 & 29 & 110 & 110 & 110 \\
\hline $2: 00 \mathrm{am}$ & 105 & 53 & 155 & 155 & 155 & 74 & 37 & 110 & 110 & 110 \\
\hline $3: 00 \mathrm{am}$ & 42 & 42 & 155 & 155 & 155 & 29 & 29 & 110 & 110 & 110 \\
\hline $4: 00 \mathrm{am}$ & 42 & 42 & 155 & 155 & 155 & 29 & 29 & 110 & 110 & 110 \\
\hline $5: 00 \mathrm{am}$ & 42 & 42 & 155 & 155 & 62 & 29 & 29 & 110 & 110 & 44 \\
\hline $6: 00 \mathrm{am}$ & 42 & 53 & 155 & 155 & 62 & 29 & 37 & 110 & 110 & 44 \\
\hline $7: 00 \mathrm{am}$ & 8.4 & 21 & 31 & 12 & 16 & 5.4 & 14 & 20 & 8.1 & 10 \\
\hline $8: 00 \mathrm{am}$ & 0 & 0 & 0 & 0 & 21 & 0 & 0 & 49 & 0 & 14 \\
\hline $9: 00 \mathrm{am}$ & 0 & 0 & 0 & 0 & 0 & 0 & 0 & 0 & 0 & 0 \\
\hline $\begin{array}{l}24 \text { hour } \\
\text { average }\end{array}$ & 25.1 & 19.4 & 40.0 & 45.7 & 45.5 & 24.3 & 13.1 & 30.4 & 32.4 & 32.2 \\
\hline
\end{tabular}


Model 2 (Turner, 1969)

\begin{tabular}{|c|c|c|c|c|c|c|c|c|c|c|}
\hline & \multicolumn{5}{|c|}{ Site A } & \multicolumn{5}{|c|}{ Site B } \\
\hline Hour (LT) & $\begin{array}{l}\text { Mar. } \\
7-8\end{array}$ & $\begin{array}{l}\text { Mar. } \\
8-9\end{array}$ & $\begin{array}{l}\text { Aug. } \\
5-6\end{array}$ & $\begin{array}{l}\text { Aug. } \\
6-7\end{array}$ & $\begin{array}{l}\text { Aug. } \\
7-8\end{array}$ & $\begin{array}{l}\text { Mar. } \\
7-8\end{array}$ & $\begin{array}{l}\text { Mar. } \\
8-9\end{array}$ & $\begin{array}{l}\text { Aug. } \\
5-6\end{array}$ & $\begin{array}{l}\text { Aug. } \\
6-7\end{array}$ & $\begin{array}{l}\text { Aug. } \\
7-8\end{array}$ \\
\hline $10: 00 \mathrm{am}$ & 0 & 0 & 0 & 0 & 0 & 0 & 0 & 0 & 0 & 0 \\
\hline $11: 00 \mathrm{am}$ & 0 & 0 & 0 & 0 & 0 & 0 & 0 & 0 & 0 & 0 \\
\hline $12: 00 \mathrm{~N}$ & 0 & 0 & 0 & 0 & 0 & 0 & 0 & 0 & 0 & 0 \\
\hline $1: 00 \mathrm{pm}$ & 0 & 1.0 & 0 & 0 & 0 & 0 & 0 & 0 & 0 & 0 \\
\hline $2: 00 \mathrm{pm}$ & 0 & 1.7 & 0 & 0 & 0 & 0 & 0 & 0 & 0 & 0 \\
\hline $3: 00 \mathrm{pm}$ & 0 & 0 & 0 & 0 & 0 & 0 & 0 & 0 & 0 & 0 \\
\hline $4: 00 \mathrm{pm}$ & 0 & 0 & 0 & 0 & 0 & 0 & 0 & 0 & 0 & 0 \\
\hline $5: 00 \mathrm{pm}$ & 0 & 0 & 0 & 0 & 0 & 0 & 0 & 0 & 0 & 0 \\
\hline $6: 00 \mathrm{pm}$ & 0 & 3.9 & 0 & 0 & 0 & 0 & 0 & 0 & 0 & 0 \\
\hline $7: 00 \mathrm{pm}$ & 0 & 0 & 0 & 0 & 0 & 0 & 0 & 0 & 0 & 0 \\
\hline $8: 00 \mathrm{pm}$ & 9.8 & 0 & 0 & 0 & 0 & 0 & 0 & 0 & 0 & 0 \\
\hline $9: 00 \mathrm{pm}$ & 0 & 0 & 0 & 0 & 0 & 85 & 0 & 0 & 0 & 0 \\
\hline $10: 00 \mathrm{pm}$ & 38 & 0 & 0 & 0 & 0 & 35 & 0 & 0 & 0 & 0 \\
\hline $11: 00 \mathrm{pm}$ & 38 & 19 & 0 & 0 & 56 & 35 & 17 & 0 & 0 & 52 \\
\hline $12: 00 \mathrm{mid}$ & 15 & 38 & 0 & 56 & 56 & 14 & 35 & 0 & 52 & 52 \\
\hline $1: 00 \mathrm{am}$ & 15 & 15 & 56 & 56 & 56 & 14 & 14 & 52 & 52 & 52 \\
\hline $2: 00 \mathrm{am}$ & 38 & 19 & 56 & 56 & 56 & 35 & 17 & 52 & 52 & 52 \\
\hline $3: 00 \mathrm{am}$ & 15 & 15 & 56 & 56 & 56 & 14 & 14 & 52 & 52 & 52 \\
\hline $4: 00 \mathrm{am}$ & 15 & 15 & 56 & 56 & 56 & 14 & 14 & 52 & 52 & 52 \\
\hline $5: 00 \mathrm{am}$ & 15 & 15 & 56 & 56 & 23 & 14 & 14 & 52 & 52 & 21 \\
\hline $6: 00 \mathrm{am}$ & 15 & 19 & 56 & 56 & 23 & 14 & 17 & 52 & 52 & 21 \\
\hline $7: 00 \mathrm{am}$ & 5.3 & 13 & 20 & 7.8 & 9.8 & 2.2 & 5.5 & 8.2 & 3.3 & 4.1 \\
\hline $8: 00 \mathrm{am}$ & 0 & 0 & 0 & 0 & 13 & 0 & 0 & 20 & 0 & 5.5 \\
\hline $9: 00 \mathrm{am}$ & 0 & 0 & 0 & 0 & 0 & 0 & 0 & 0 & 0 & 0 \\
\hline $\begin{array}{l}24 \text { hour } \\
\text { average }\end{array}$ & 9.1 & 7.3 & 14.8 & 16.7 & 16.9 & 11.5 & 6.1 & 14.2 & 15.3 & 15.2 \\
\hline
\end{tabular}


Model 3 (U.S. EPA, 1981)

\begin{tabular}{|l|c|c|c|c|c|c|c|c|c|c|}
\hline & \multicolumn{9}{|c|}{ Site A } & \multicolumn{5}{c|}{ Site } \\
\hline Hour (LT) & $\begin{array}{l}\text { Mar. } \\
7-8\end{array}$ & $\begin{array}{l}\text { Mar. } \\
8-9\end{array}$ & $\begin{array}{l}\text { Aug. } \\
5-6\end{array}$ & $\begin{array}{l}\text { Aug. } \\
6-7\end{array}$ & $\begin{array}{l}\text { Aug. } \\
7-8\end{array}$ & $\begin{array}{l}\text { Mar. } \\
7-8\end{array}$ & $\begin{array}{c}\text { Mar. } \\
8-9\end{array}$ & $\begin{array}{c}\text { Aug. } \\
5-6\end{array}$ & $\begin{array}{c}\text { Aug. } \\
6-7\end{array}$ & $\begin{array}{c}\text { Aug. } \\
7-8\end{array}$ \\
\hline $10: 00 \mathrm{am}$ & 0 & 0 & 0 & 0 & 0 & 0 & 0 & 0 & 0 & 0 \\
\hline $11: 00 \mathrm{am}$ & 0 & 0 & 0 & 0 & 0 & 0 & 0 & 0 & 0 & 0 \\
\hline $12: 00 \mathrm{~N}$ & 0 & 0 & 0 & 0 & 0 & 0 & 0 & 0 & 0 & 0 \\
\hline $1: 00 \mathrm{pm}$ & 0 & 1.0 & 0 & 0 & 0 & 0 & 0 & 0 & 0 & 0 \\
\hline $2: 00 \mathrm{pm}$ & 0 & 1.3 & 0 & 0 & 0 & 0 & 0 & 0 & 0 & 0 \\
\hline $3: 00 \mathrm{pm}$ & 0 & 0 & 0 & 0 & 0 & 0 & 0 & 0 & 0 & 0 \\
\hline $4: 00 \mathrm{pm}$ & 0 & 0 & 0 & 0 & 0 & 0 & 0 & 0 & 0 & 0 \\
\hline $5: 00 \mathrm{pm}$ & 0 & 0 & 0 & 0 & 0 & 0 & 0 & 0 & 0 & 0 \\
\hline $6: 00 \mathrm{pm}$ & 0 & 2.4 & 0 & 0 & 0 & 0 & 0 & 0 & 0 & 0 \\
\hline $7: 00 \mathrm{pm}$ & 0 & 0 & 0 & 0 & 0 & 0 & 0 & 0 & 0 & 0 \\
\hline $8: 00 \mathrm{pm}$ & 6.0 & 0 & 0 & 0 & 0 & 0 & 0 & 0 & 0 & 0 \\
\hline $9: 00 \mathrm{pm}$ & 0 & 0 & 0 & 0 & 0 & 21 & 0 & 0 & 0 & 0 \\
\hline $10: 00 \mathrm{pm}$ & 20 & 0 & 0 & 0 & 0 & 20 & 0 & 0 & 0 & 0 \\
\hline $11: 00 \mathrm{pm}$ & 20 & 10 & 0 & 0 & 30 & 20 & 9.8 & 0 & 0 & 29 \\
\hline $12: 00 \mathrm{mid}$ & 8.1 & 20 & 0 & 30 & 30 & 7.8 & 20 & 0 & 29 & 29 \\
\hline $1: 00 \mathrm{am}$ & 8.1 & 8.0 & 30 & 30 & 30 & 7.8 & 7.8 & 29 & 29 & 29 \\
\hline $2: 00 \mathrm{am}$ & 20 & 10 & 30 & 30 & 30 & 20 & 9.8 & 29 & 29 & 29 \\
\hline $3: 00 \mathrm{am}$ & 8.1 & 8.0 & 30 & 30 & 30 & 7.8 & 7.8 & 29 & 29 & 29 \\
\hline $4: 00 \mathrm{am}$ & 8.1 & 8.0 & 30 & 30 & 30 & 7.8 & 7.8 & 29 & 29 & 29 \\
\hline $5: 00 \mathrm{am}$ & 8.1 & 8.0 & 30 & 30 & 12 & 7.8 & 7.8 & 29 & 29 & 12 \\
\hline $6: 00 \mathrm{am}$ & 8.1 & 10 & 30 & 30 & 12 & 7.8 & 9.8 & 29 & 29 & 12 \\
\hline $7: 00 \mathrm{am}$ & 3.6 & 8.9 & 13 & 5.2 & 6.5 & 3.4 & 8.6 & 13 & 5.1 & 6.4 \\
\hline $8: 00 \mathrm{am}$ & 0 & 0 & 0 & 0 & 8.7 & 0 & 0 & 14 & 0 & 8.5 \\
\hline $9: 00 \mathrm{am}$ & 0 & 0 & 0 & 0 & 0 & 0 & 0 & 0 & 0 & 0 \\
\hline $\begin{array}{l}24 \mathrm{hour} \\
\text { average }\end{array}$ & 4.9 & 4.0 & 8.0 & 9.0 & 9.1 & 5.5 & 3.7 & 8.4 & 8.7 & 8.9 \\
\hline
\end{tabular}


Model 4 (Gifford and Hanna, 1970)

\begin{tabular}{|c|c|c|c|c|c|c|c|c|c|c|}
\hline \multirow[b]{2}{*}{ Hour (LT) } & \multicolumn{5}{|c|}{ Site A } & \multicolumn{5}{|c|}{ Site B } \\
\hline & $\begin{array}{l}\text { Mar. } \\
7-8\end{array}$ & $\begin{array}{l}\text { Mar. } \\
8-9\end{array}$ & $\begin{array}{l}\text { Aug. } \\
5-6\end{array}$ & $\begin{array}{l}\text { Aug. } \\
6-7\end{array}$ & \begin{tabular}{|l|} 
Aug. \\
$7-8$
\end{tabular} & $\begin{array}{l}\text { Mar. } \\
7-8\end{array}$ & $\begin{array}{l}\text { Mar. } \\
8-9\end{array}$ & $\begin{array}{l}\text { Aug. } \\
5-6\end{array}$ & \begin{tabular}{|l|} 
Aug. \\
$6-7$
\end{tabular} & $\begin{array}{l}\text { Aug. } \\
7-8\end{array}$ \\
\hline$\overline{10: 00 a m}$ & 0 & 0 & 0 & 0 & 0 & 0 & 0 & 0 & 0 & 0 \\
\hline $11: 00 \mathrm{am}$ & 0 & 0 & 0 & 0 & 0 & 0 & 0 & 0 & 0 & 0 \\
\hline $12: 00 \mathrm{~N}$ & 0 & 0 & 0 & 0 & 0 & 0 & 0 & 0 & 0 & 0 \\
\hline $1: 00 \mathrm{pm}$ & 0 & 37 & 0 & 0 & 0 & 0 & 0 & 0 & 0 & 0 \\
\hline $2: 00 \mathrm{pm}$ & 0 & 34 & 0 & 0 & 0 & 0 & 0 & 0 & 0 & 0 \\
\hline $3: 00 \mathrm{pm}$ & 0 & 0 & 0 & 0 & 0 & 0 & 0 & 0 & 0 & 0 \\
\hline $4: 00 \mathrm{pm}$ & 0 & 0 & 0 & 0 & 0 & 0 & 0 & 0 & 0 & 0 \\
\hline $5: 00 \mathrm{pm}$ & 0 & 0 & 0 & 0 & 0 & 0 & 0 & 0 & 0 & 0 \\
\hline $6: 00 \mathrm{pm}$ & 0 & 42 & 0 & 0 & 0 & 0 & 0 & 0 & 0 & 0 \\
\hline $7: 00 \mathrm{pm}$ & 0 & 0 & 0 & 0 & 0 & 0 & 0 & 0 & 0 & 0 \\
\hline $8: 00 \mathrm{pm}$ & 67 & 0 & 0 & 0 & 0 & 0 & 0 & 0 & 0 & 0 \\
\hline $9: 00 \mathrm{pm}$ & 0 & 0 & 0 & 0 & 0 & 69 & 0 & 0 & 0 & 0 \\
\hline $10: 00 \mathrm{pm}$ & 179 & 0 & 0 & 0 & 0 & 135 & 0 & 0 & 0 & 0 \\
\hline $11: 00 \mathrm{pm}$ & 179 & 89 & 0 & 0 & 263 & 135 & 67 & 0 & 0 & 201 \\
\hline $12: 00 \mathrm{mid}$ & 71 & 179 & 0 & 263 & 263 & 54 & 135 & 0 & 201 & 201 \\
\hline $1: 00 \mathrm{am}$ & 71 & 72 & 263 & 263 & 263 & 54 & 54 & 201 & 201 & 201 \\
\hline $2: 00 \mathrm{am}$ & 179 & 89 & 263 & 263 & 263 & 135 & 67 & 201 & 201 & 201 \\
\hline $3: 00 \mathrm{am}$ & 71 & 72 & 263 & 263 & 263 & 54 & 54 & 201 & 201 & 201 \\
\hline $4: 00 \mathrm{am}$ & 71 & 72 & 263 & 263 & 263 & 54 & 54 & 201 & 201 & 201 \\
\hline $5: 00 \mathrm{am}$ & 71 & 72 & 263 & 263 & 105 & 54 & 54 & 201 & 201 & 80 \\
\hline $6: 00 \mathrm{am}$ & 71 & 89 & 263 & 263 & 105 & 54 & 67 & 201 & 201 & 80 \\
\hline $7: 00 \mathrm{am}$ & 71 & 179 & 263 & 105 & 131 & 54 & 135 & 201 & 80 & 100 \\
\hline $8: 00 \mathrm{am}$ & 0 & 0 & 0 & 0 & 175 & 0 & 0 & 100 & 0 & 134 \\
\hline 9:00am & 0 & 0 & 0 & 0 & 0 & 0 & 0 & 0 & 0 & 0 \\
\hline $\begin{array}{l}24 \text { hour } \\
\text { average }\end{array}$ & 45.9 & 42.8 & 76.7 & 81.1 & 87.3 & 35.5 & 28.6 & 62.8 & 62.0 & 66.7 \\
\hline
\end{tabular}

